УДК 552.11

DOI: https://doi.org/10.17308/geology.2021.4/3787

ISSN 1609-0691

Поступила в редакцию: 28.11 .2021

Принята к публикации: 01.12.2021

Опубликована онлайн: 17.12.2021

\title{
Палеопротерозойские гранодиориты І-типа Луневского массива в Курском блоке Сарматии: U-Pb возраст, изотопная систематика и источники расплавов
}

\author{
(C) 2021 К. А. Савко ${ }^{1 凶}$, Е. Х. Кориш ${ }^{1}$, Н. С. Базиков ${ }^{1}$, С. В. Цыбуляев ${ }^{1}$, В. С. Червяков- \\ ский ${ }^{2}$ Н. В. Холина ${ }^{1}$, И. Хуссейн ${ }^{1}$ \\ ${ }^{I}$ Воронежский государственный университет, Университетская пл., 1, 394018, Воронеж, \\ Российская Федерация \\ ${ }^{2}$ Институт геологии и геохимии им. А.Н. Заварицкого, Уральского отделения Российской \\ академии наук, ул. Вонсовского, 15, 620016, Екатеринбург, Российская Федерация
}

\begin{abstract}
Аннотация
Bведение: Полученные в последнее время датировки возраста и изотопно-геохимические данные для пород Курского блока позволяют полностью пересмотреть историю роста коры Восточной Сарматии в раннем докембрии. Однако имеется очень немного данных о возрасте, изотопной и элементной геохимии гранодиорит-диоритовых массивов, представляющих собой наиболее объемное проявление палеопротерозойского магматического события в Курском блоке. Настоящая статья вносит вклад в решение этой проблемы и посвящена Луневскому массиву гранодиоритов.

Методика: Для определения возраста образования и источников расплавов гранодиоритов было проведено геохимическое и $\mathrm{U}-\mathrm{Pb}, \mathrm{Lu}-\mathrm{Hf}$ и $\mathrm{Sm}-\mathrm{Nd}$ изучение пород Луневского массива.

Результаты и обсуждение: Гранодиориты Луневского массива принадлежат к гранитоидам I-типа и имеют адакитовые геохимические характеристики. Возраст кристаллизации массива составляет 2040 млн лет. Он имеет посттектоническую позицию.

Заключение: Изотопный состав Нf в цирконе указывает на участие в образовании гранодиоритового расплава нескольких источников, включающих коровые палеоархейские и ювенильные мантийные палеопротерозойские протолиты.

Ключевые слова: Курский блок, палеопротерозой, гранодиориты, U-Pb изотопный возраст, источники расплавов, изотопная систематика

Источник финансирования: LA-ICP-MS исследование проведено в ЦКП "Геоаналитик" ИГГ УрО РАН в рамках темы № АAАA-А18-118053090045-8 государственного задания ИГГ УрО РАН. Дооснащение и комплексное развитие ЦКП "Геоаналитик" ИГГ УрО РАН осуществляется при финансовой поддержке гранта Министерства науки и высшего образования Российской Федерации, Соглашение № 075-15-2021-680
\end{abstract}

Для цитирования: Савко К. А., Кориш Е. Х., Базиков Н. С., Цыбуляев С. В., Червяковский В. С., Холина Н. В., Хуссейн И. Палеопротерозойские гранодиориты І-типа Луневского массива в Курском блоке Сарматии: U-Pb возраст, изотопная систематика и источники расплавов // Вестник Воронежского государственного университета. Серия: Геология. 2021. №4. С. 4-23. DOI: https://doi.org/10.17308/geology.2021.4/3787

\footnotetext{
$\bowtie$ Савко Константин Аркадьевич, e-mail: ksavko@geol.vsu.ru
} 


\section{Введение}

За последние несколько лет нами были получены прецизионные датировки возраста и изотопно-геохимические данные для раннедокембрийских пород Курского блока, что позволило выявить крупное магматическое событие на рубеже 2.06 млрд лет $[1,2]$ и полностью пересмотреть историю роста коры Восточной Сарматии в раннем докембрии. В период 2.05-2.07 млрд лет произошло внедрение в кору большого объема магм различного состава, представленных в Курском блоке диорит-гранодиоритовым стойло-николаевским [1, 3], габбро-сиенитовым шебекинским [4] и габброидным золотухинским [5] комплексами, вулканитами бимодальной серии курбакинской и андезитами глазуновской свит $[6,7]$.

Палеопротерозойские гранодиорит-диоритовые массивы в архейском Курском блоке Сарматии сконцентрированы в палеопротерозойской Тим-Ястребовской внутриконтинентальной рифтовой структуре (рис. 1, 2), хотя встречаются и за ее пределами [3]. Они представляют наиболее объемное проявление мощного палеопротерозойского магматического события в Курском блоке Сарматии. Несмотря на большое количество массивов и многочисленных даек диоритов и гранодиоритов стойло-николаевского комплекса, вскрытых помимо скважин еще и в железорудных карьерах Курской магнитной аномалии, данных об их возрасте, изотопной и элементной геохимии очень немного $[1,3]$. В связи с этим, суждения об источниках расплавов и петрогенезисе объемного палеопротерозойского диорит-гранодиоритового магматизма сталкиваются с многочисленными неопределенностями.

Настоящая статья призвана внести вклад в решение проблем петрогенезиса палеопротерозойского кислого магматизма Курского блока. Ее цель - определение возраста образования и источников расплавов Луневского массива гранодиоритов в Тим-Ястребовской рифтогенной структуре на основе их геохимического изучения, $\mathrm{U}-\mathrm{Pb}, \mathrm{Lu}-\mathrm{Hf}$, и $\mathrm{Sm}-\mathrm{Nd}$ изотопной систематики.

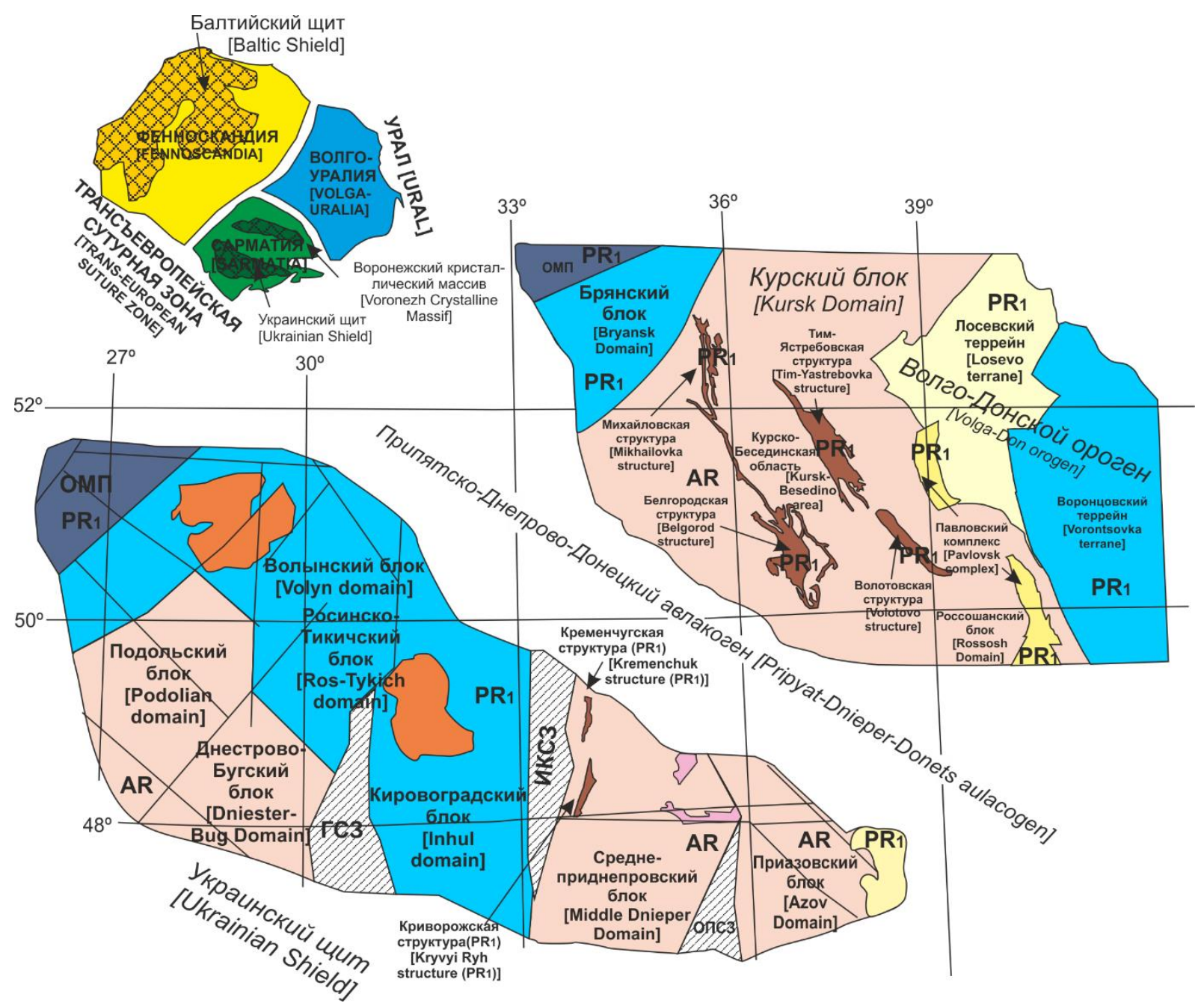

Рис. 1. Схематическая структурная карта Сарматии, составленная по [8] для Украинского щита и по собственным материалам для Воронежского кристаллического массива. Аббревиатуры: ГСЗ - Голованевская сутурная зона, ИКСЗ - Ингулец-Криворожская сутурная зона, ОПСЗ - Орехово-Павлоградская сутурная зона, ОМП - Осницко-Микашевичский пояс.

[Fig. 1. A sketch map of the Sarmatia, compiled after [8] for Ukrainian Shield, and authors data (for Voronezh Crystalline Massif). Abbreviations: ГС - Golovanevsk Suture Zone, ИКС3 - Ingulets-Krivoy Rog Suture Zone, ОПС3 - Orekhovo-Pavlograd Suture Zone, OMП - Osnitsk-Mikashevichi Igneous Belt.] 


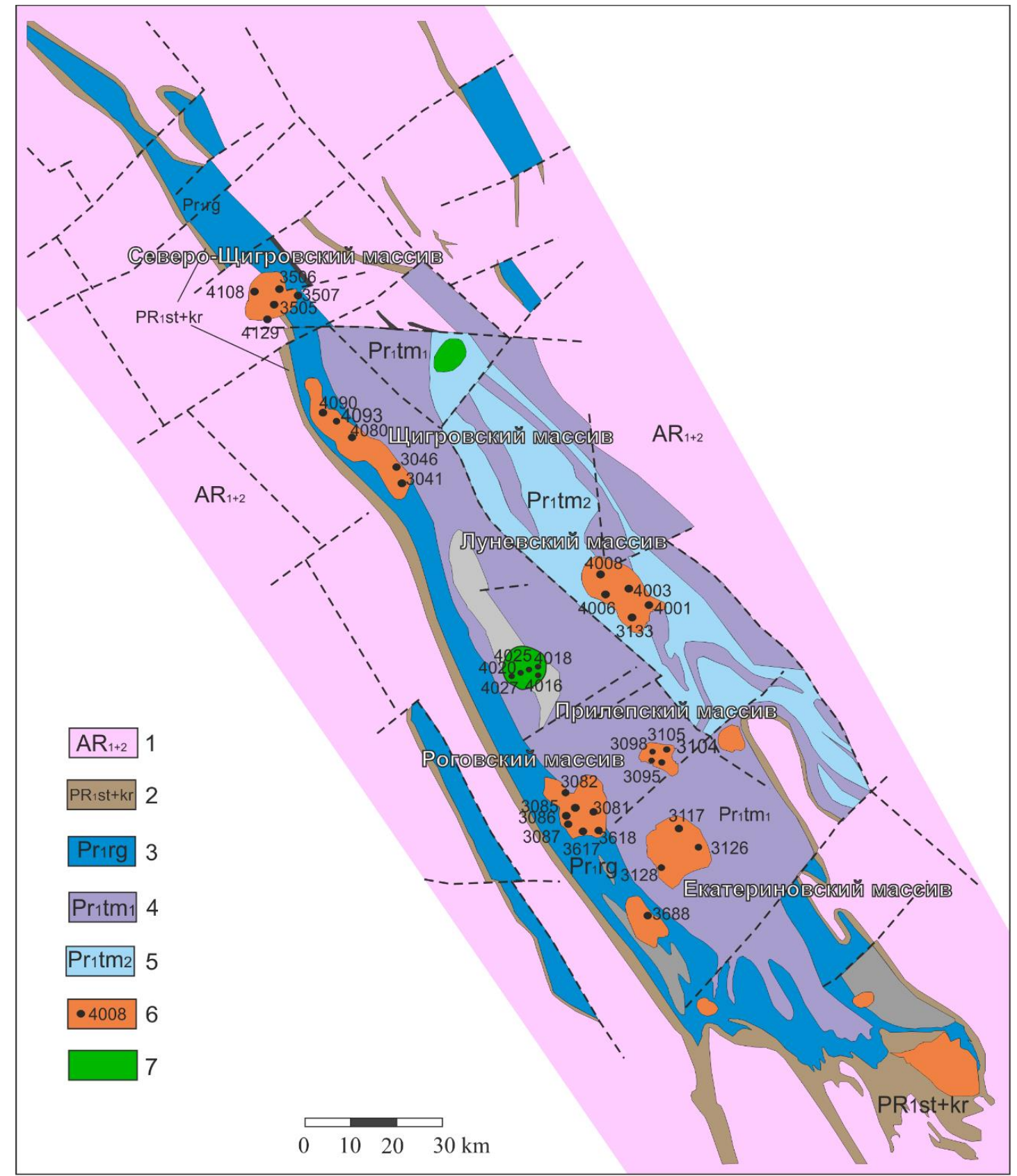

Рис. 2. Схематическая геологическая карта Тим-Ястребовской структуры: 1 - ТТГ-ассоциация и метабазиты $\left(\mathrm{AR}_{1+2}\right) ; 2-$ cтойленская и коробовская свиты курской серии ( $\left.\mathrm{PR}_{1} \mathrm{st}+\mathrm{kr}\right) ; 3$ - роговская свита оскольской серии $\left(\mathrm{PR}_{1} \mathrm{rg}\right) ; 4-$ нижняя подсвита тимской свиты оскольской серии $\left(\mathrm{PR}_{1} \mathrm{tm}_{1}\right) ; 5$ - верхняя подсвита тимской свиты оскольской серии $\left(\mathrm{PR}_{1} \mathrm{tm}_{2}\right) ; 6$ - гранитоиды стойло-николаевского комплекса, местоположение и номера пробуренных скважин; 7 - габброиды.

[Fig. 2. Schematic geological map of the Tim-Yastrebovka structure: (1) - TTG association and metabasites (AR $1+2)$; (2) - Stoilo and Korobki formations of the Kursk Group ( $\left.\mathrm{PR}_{1} \mathrm{st}+\mathrm{kr}\right)$; (3) - Rogovoe Formation of the Oskol Group ( $\mathrm{PR}_{1} \mathrm{rg}$ ); (4) - lower subformation of the Tim Formation of the Oskol Group ( $\left.\mathrm{PR}_{1} \mathrm{tm}_{1}\right)$; (5) - upper subformation of the Tim Formation of the Oskol Group $\left(\mathrm{PR}_{1} \mathrm{tm}_{2}\right)$; (6) - StoiloNikolaev Complex and drill-holes; (7) - gabbroids. Inscriptions on the picture: Северо-Щигровский массив - North Shigry Massif, Щигровский массив - Shigry Massif, Луневский массив - Lunevsky Massif, Прилепский массив - Prilepy Маssif, Роговский массив - Rogovoе Massif, Екатериновский массив - Ekaterinovsky Massif.]

\section{Геологическая позиция}

Луневский массив и другие крупные диорит-гранодиоритовые массивы (Роговский, Екатериновский, Щигровский и др.) в Курском блоке Сарматии находится в пределах палеопротерозойской Тим-Ястребовской внутриконтинентальной рифтовой структуры (рис. 2).
Интрузивный магматизм в Тим-Ястребовской структуре и ее обрамлении представлен, преимущественно, диорит-гранодиоритовыми массивами, небольшими интрузиями и силлами амфиболовых габбро, прорывающими палеопротерозойские метаморфизованные вулканогенно-осадочные толщи (рис. 2). Интрузии гранитоидов образуют изометричные и 
вытянутые в северо-западном или субмеридиональном направлении массивы и штокообразные тела площа-

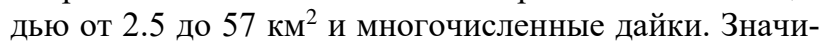
тельно реже встречаются интрузии габбро, самая крупная из них Гнилушинская имеет площадь около 9 км². Все интрузии отчетливо дискордантные, секут складчатые структуры вмещающих палеопротерозойских осадочно-метаморфических толщ курской (терригенные породы и железистые кварциты) и оскольской (терригенные, карбонатные породы и метабазальты) серий. Контакты четкие, резкие, секущие. Вмещающие породы на контакте ороговикованы, скарнированы и рассечены многочисленными апофизами интрузий. Вблизи интрузий во вмещающих породах развита контактово-метаморфическая зональность, но признаки плавления отсутствуют. Отдельные массивы имеют зональное строение. Их периферические зоны сложены диоритами, которые через кварцевые диориты постепенно переходят в гранодиориты в центральных частях интрузий.

В экзоконтактовых зонах массивов гранитоидов присутствуют многочисленные дайки, жилы и апофизы диоритов, гранодиоритов таких же по составу, как и в самих интрузиях. В дайках и жилах гранитоиды более мелкозернистые, чем в массивах, имеют выраженную порфировидную структуру. В эндоконтактовых зонах массивов часто присутствуют ксенолиты вмещающих пород размером от 0.1 до $3.0 \mathrm{M}$.

Магнитные аномалии в пределах массивов не поддаются однозначной интерпретации, являясь продолжением высокоинтенсивных магнитных аномалий от железорудной толщи курской серии. Они, возможно, вызваны крутопадающими толщами железистых кварцитов, не выходящих на эрозионный раннедокембрийский срез. Гранодиоритовые массивы довольно контрастно проявляются в гравитационном поле. Выделение их проводится по локальным минимумам вертикальных производных силы тяжести.

Луневский массив гранодиоритов расположен в восточной части Тим-Ястребовской структуры. В плане массив имеет округлую изометричную форму (рис. 2).

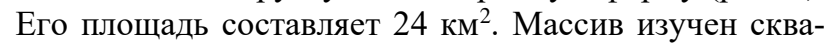
жинами: 4001, 4003, 4006, 4008 и 3133 на глубину от 8.0 м (скв. 4003) до 190.0 м (скв. 4006). Керн скважин 3133 и 4003 был утрачен. Диориты скважинами вскрыты не были. Вмещающими породами являются кислые и основные вулканиты тимской свиты. В контактовых зонах риолиты и дациты грейзенизированы с новообразованиями кварца и мусковита, часто содержат турмалин и флюорит. Основные вулканиты превращены в пироксеновые роговики.

\section{Методы исследований}

Определение содержаний главных элементов в породах выполнено на рентгено-флуоресцентном спектрометре S8 Tiger (Bruker AXS GmbH, Германия) в Воронежском государственном университете. Подготовка проб для анализа породообразующих элементов выполнена путем плавления 0.5 г порошка пробы, 2 г тетрабората лития в муфельной печи с последующим отливом стеклообразного диска. При калибровке спектрометра и для контроля качества измерений были использованы государственные стандартные образцы химического состава горных пород - ГСО №8871-2007, ГСО № 3333-85, ГСО № 3191-85. Точность анализа составляла $1-5 \%$ отн. \% для элементов с концентрациями выше 1-5 мас. \% и до 12 отн. \% для элементов с концентрацией ниже 0.5 мас. \%. Обработка результатов проводилась посредством разработанных методик в программе Spectra Plus (Bruker AXS GmbH, Германия).

Локальные анализы минералов выполнены на электронном микроскопе Jeol 6380LV с системой количественного энергодисперсионного анализа «Inca» (ЦКПНО ВГУ). Условия анализа: ускоряющее напряжение 20 кВ, ток зонда 1.2 мА, время набора спектра 90 сек, диаметр пучка 1-3 мкм. ZAF коррекция при расчете содержания окислов и оценка точности проводились с помощью комплекта программ математического обеспечения системы. Точность анализа систематически контролировалась по эталонным образцам природных и синтетических минералов.

Малые и редкие элементы определялись методом индукционно-связанной плазмы с масс-спектрометрическим окончанием анализа (ICP-MS) во Всероссийском научно-исследовательском геологическом институте им. А.П. Карпинского (ВСЕГЕИ). Разложение образцов пород осуществлялось сплавлением с метаборатом лития. Перевод образующейся смеси твердых комплексных оксидов в раствор осуществляли с помощью азотной кислоты. Правильность анализа контролировали путем измерения международных и российских стандартных образцов GSP-2, ВМ, СГД-1А, СТ-1. Ошибки определения концентраций составляли от 3 до 5 мас. \% для большинства элементов.

Выделение акцессорного циркона проводилось по стандартной методике с использованием тяжелых жидкостей. U-Th-Pb геохронологические исследования выполнены в ЦИИ ВСЕГЕИ (г. Санкт-Петербург) на ионном микрозонде SHRIMP II по методике [9] с использованием эталонных цирконов “91500” и “Теmora”. При расчетах использованы константы распада урана [10]. Поправки на нерадиогенный свинец введены по модели [11] на основе измеренных отношений ${ }^{204} \mathrm{~Pb} /{ }^{206} \mathrm{~Pb}$. Полученные результаты обработаны с помощью программы SQUID [12].

$\mathrm{Sm}-\mathrm{Nd}$ изотопные исследования выполнены во ВСЕГЕИ на многоколлекторном масс-спектрометре Triton TI в статическом режиме. Коррекция на изотопное фракционирование неодима производилась с помощью нормализации измеренных значений по отношению ${ }^{146} \mathrm{Nd} /{ }^{144} \mathrm{Nd}=0.7219$. Нормализованные отношения приводились к значению ${ }^{143} \mathrm{Nd} /{ }^{144} \mathrm{Nd}=0.512115$ в международном изотопном стандарте JNdi-1. Погрешность определения содержаний $\mathrm{Sm}$ и $\mathrm{Nd}$ составляла $0.5 \%$, изотопных отношений ${ }^{147} \mathrm{Sm} /{ }^{144} \mathrm{Nd}-\square \pm 0.5$ $\%,{ }^{143} \mathrm{Nd} /{ }^{144} \mathrm{Nd}- \pm 0.002 \%(2 \sigma)$. Уровень холостого опыта не превышал 10 пг для $\mathrm{Sm}$ и 20 пг для $\mathrm{Nd}$. При расчете величин $\varepsilon \mathrm{Nd}(\mathrm{T})$ использовались современные 
значения однородного хондритового резервуара (CHUR) с параметрами ${ }^{147} \mathrm{Sm} /{ }^{144} \mathrm{Nd}=0.1967$, ${ }^{143} \mathrm{Nd} /{ }^{144} \mathrm{Nd}=0.512638$

Изучение Lu-Hf-изотопного состава цирконов выполнено на многоколлекторном масс-спектрометре Neptune Plus c приставкой для лазерной абляции NWR 213 в Институте геологии и геохимии им. академика А.Н. Заварицкого УрО РАН, г. Екатеринбург. Выполнена оптимизация процедуры обработки экспериментальных данных со стандартами циркона Mud Tank, GJ-1 [13]. Неопределенность единичного измерения отношения ${ }^{176} \mathrm{Hf} /{ }^{177} \mathrm{Hf}$ в виде $2 \mathrm{SD}$ - в интервале $0.005-$ $0.008 \%$, единичного определения значения $\varepsilon(\mathrm{Hf})$ в виде 2SD варьировала для перечисленных стандартов в интервале 5-9 \%. Параметры процесса лазерной абляции: плотность энергии лазерного излучения -14

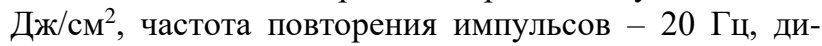

аметр кратера - 25 мкм. Для обработки Lu-Hf данных был использован макрос Hf-INATOR для Excel [14].

\section{Петрография}

Гранодиориты, изученные в скважинах 4001, 4006 и 4008 , розовато-серого и светло-серого цвета среднезернистые, иногда порфировидные. Текстура гранодиоритов массивная участками такситовая, структура гипидиоморфнозернистая, порфировидная, обусловленная наличием крупных зерен микроклина размером $1.0-1.5$ см (рис. 3). По минеральному составу породы довольно однообразны - сложены плагиоклазом, микроклином, биотитом, кварцем. В отличие от гранодиоритов других массивов [1] роговая обманка нами не встречена. Акцессорные минералы представлены титанитом, ильменитом, сульфидами, цирконом, вторичные - эпидот, серицит, карбонат, хлорит.
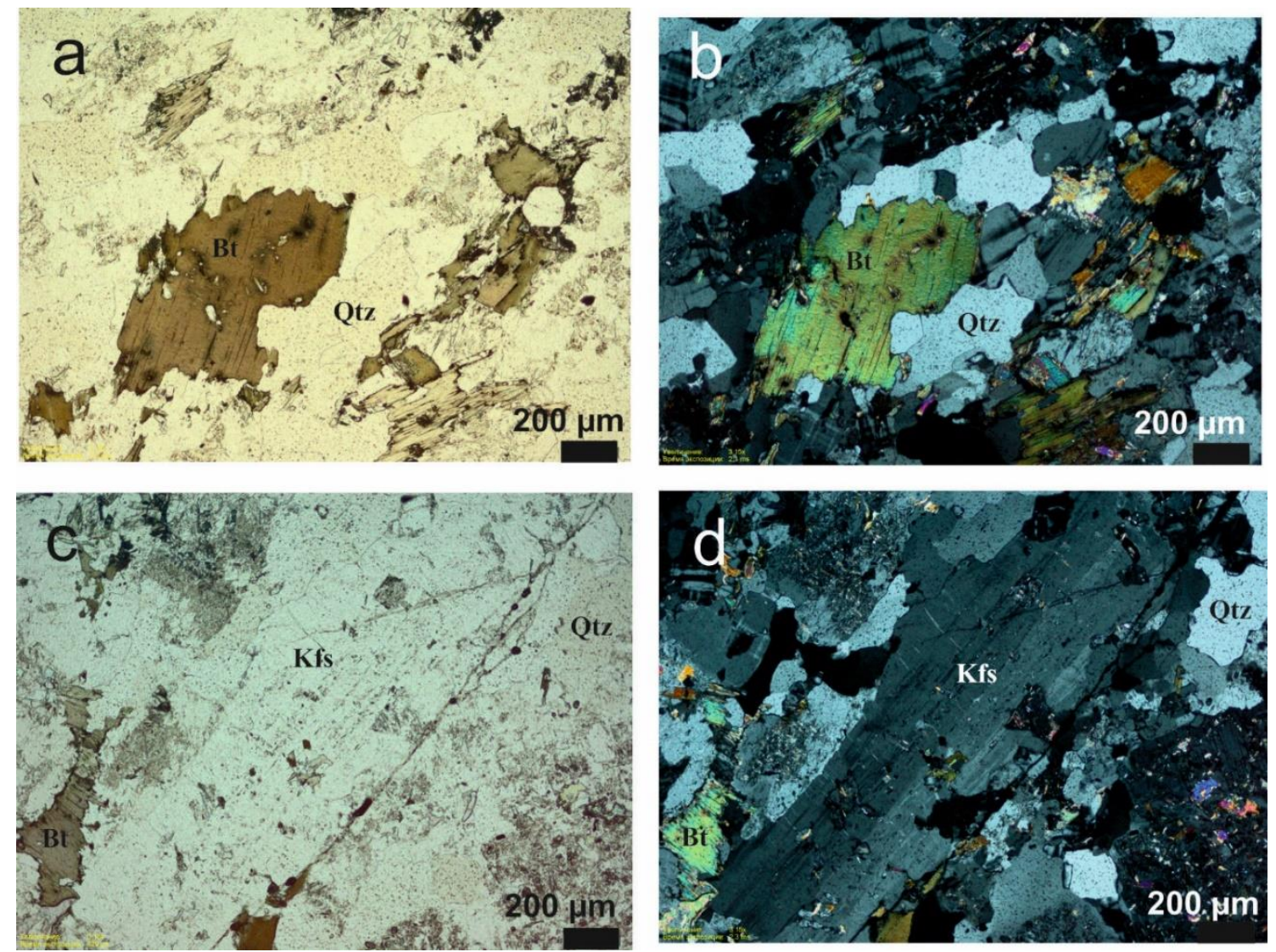

Рис. 3. Фото шлифов гранодиориов Луневского массива: $a, b$ - образец 4006/252.5; $c, d$ - образец 4008/217.8 в проходящем и поляризованном свете. Аббревиатура минералов по [15].

[Fig. 3. Photomicrographs of the granodiorites thin sections of the Lunevsky Massif: $(a, b)-$ sample 4006/252.5; $(c, d)-$ sample 4008/217.8 in transmitted and polarized light. Mineral abbreviations after [15]].

В гранодиоритах плагиоклаз присутствует в количестве от 40 до 60 мас. \% и представлен удлиненными и таблитчатыми идиоморфными зернами размером 0.5-2.0 мм. По составу он отвечает олигоклазу и имеет зональность от $A b_{76-78}$ в центральных частях до $A b_{84-87}$ в краевых. Биотит встречается в виде лейст размером 0.2-1.0 мм в количестве до 10 мас. \% (рис. 3 a, b). Лейсты биотита плеохроируют от густо-буро-зеленого до светло-коричневого цвета и бывают наполнены мелкими включениями титанита, эпидота, алланита, циркона с плеохроичными двориками. По составу биотит среднежелезистый $\left(\mathrm{X}_{\mathrm{Fe}}=0.58-0.61\right)$, довольно глиноземистый $\left(\mathrm{Al}_{2} \mathrm{O}_{3}=16.0-17.2\right.$ мас. \%) с умеренными содержаниями титана $\left(\mathrm{TiO}_{2}=1.0-2.4\right.$ мас. \%). Микроклин в количестве 15-25 мас. \% встречается как в виде решетчатых мелких зерен в основной массе, так и в виде 
крупных порфировых выделений (от 2-4 мм до 1.5 см). В крупных зернах микроклина отмечаются включения биотита, плагиоклаза, кварца (рис 3 c, d). На контакте с зернами плагиоклаза часто отмечается мирмекитовая структура. По составу это почти чистый калиевый полевой шпат с незначительной примесью альбитового ( $<11 \%$ ) компонента. Квари присутствует в количестве до 15-20 мас. \% и образует изометричные и ксеноморфные зерна размером 0.1-0.8 мм с неровными границами и содержит микроскопические включения игольчатых кристаллов рутила. Обогащенные рутилом зерна имеют в образце голубоватый цвет.

Из акцессорных минералов наиболее характерным является титанит, образующий довольно крупные (0.02-0.2 мм) красновато-коричневые кристаллы с ромбическими и клиновидными сечениями. Рудные минералы представлены ильменитом, пиритом, пирротином, реже халькопиритом. Среди вторичных минералов резко преобладают минералы группы эпидотаклиноцоизита.

\section{Геохимия}

В скважинах, вскрывших Луневский массив, нам не удалось обнаружить диоритов, хотя, возможно, они присутствуют в его строении. Поэтому геохимическая характеристика массива приводится только для 17 образцов гранодиоритов из трех скважин (4001, 4006, 4008). Они имеют довольно узкий интервал содержаний $\mathrm{SiO}_{2}$ от 65.6 до 68.4 мас. \% (среднее 67.0 мас. \%) и довольно высокие значения суммы щелочей $\left(\mathrm{K}_{2} \mathrm{O}+\mathrm{Na}_{2} \mathrm{O}=7.8-9.3\right.$, cp. 8.5 мас. \%) в основном c близкими концентрациями калия и натрия $\left(\mathrm{K}_{2} \mathrm{O} / \mathrm{Na}_{2} \mathrm{O}=0.76-1.42\right.$, ср. 1.05) (табл. 1). Гранодиориты Луневского массива характеризуются умеренными содержаниями кальция $(\mathrm{CaO}=2.3-3.3$ мас. \%), фocфopa $\left(\mathrm{P}_{2} \mathrm{O}_{5}=0.11-0.23\right.$ мас. \%) и титана $\left(\mathrm{TiO}_{2}=\right.$ 0.26-0.49 мас. \%), являются в основном метаглиноземистыми $(\mathrm{A} / \mathrm{CNK}<1)$ (рис. 4) и довольно железистыми $\left(\mathrm{X}_{\mathrm{Fe}}=0.45-0.79\right.$, cp. 0.68).

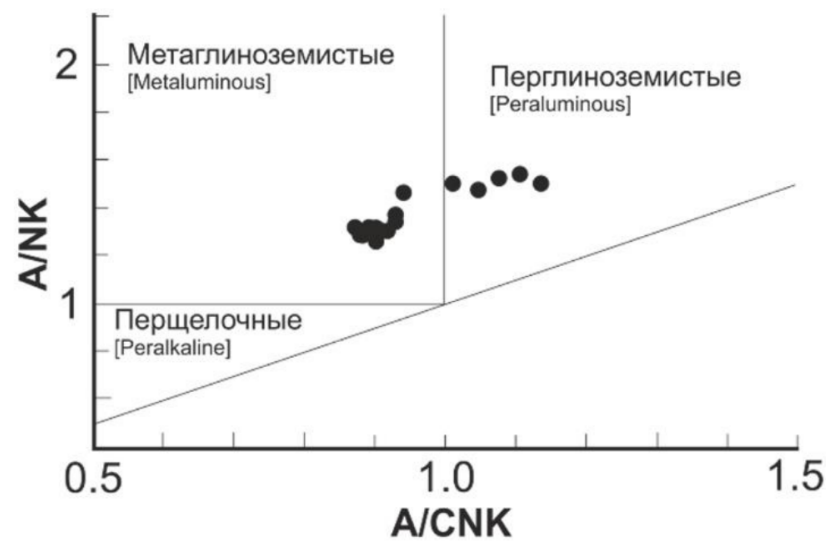

Рис. 4. Составы гранодиоритов Луневского массива на диаграмме $\mathrm{A} / \mathrm{NK}$ (молярные отношения $\mathrm{Al} 2 \mathrm{O} 3 /(\mathrm{Na} 2 \mathrm{O}+\mathrm{K} 2 \mathrm{O})$ ) $\mathrm{A} / \mathrm{CNK}$ (молярные отношения $\mathrm{Al} 2 \mathrm{O} 3 /(\mathrm{CaO}+\mathrm{Na} 2 \mathrm{O}+\mathrm{K} 2 \mathrm{O})$ ).

[Fig. 4. $\mathrm{A} / \mathrm{NK}$ (molar $\mathrm{Al}_{2} \mathrm{O}_{3} /\left(\mathrm{Na}_{2} \mathrm{O}+\mathrm{K}_{2} \mathrm{O}\right.$ )) versus $\mathrm{A} / \mathrm{CNK}$ (molar $\left.\mathrm{Al}_{2} \mathrm{O}_{3} /\left(\mathrm{CaO}+\mathrm{Na}_{2} \mathrm{O}+\mathrm{K}_{2} \mathrm{O}\right)\right)$ diagram for granodiorites of the Lunevsky Massif.]

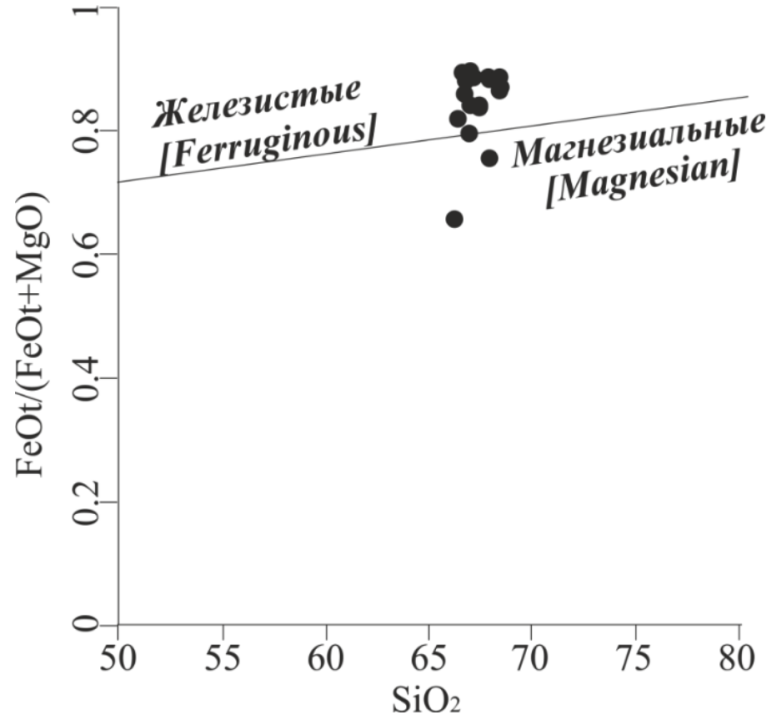

Рис. 5. Составы гранодиоритов Луневского массива на классификационной диаграмме $\mathrm{FeO}_{t} /\left(\mathrm{FeO}_{t}+\mathrm{MgO}\right)-\mathrm{SiO}_{2}$.

[Fig. 5. $\mathrm{FeO}_{1} /\left(\mathrm{FeO}_{\mathrm{t}}+\mathrm{MgO}\right)-\mathrm{SiO}_{2}$ diagram for granodiorites of the Lunevsky Massif].

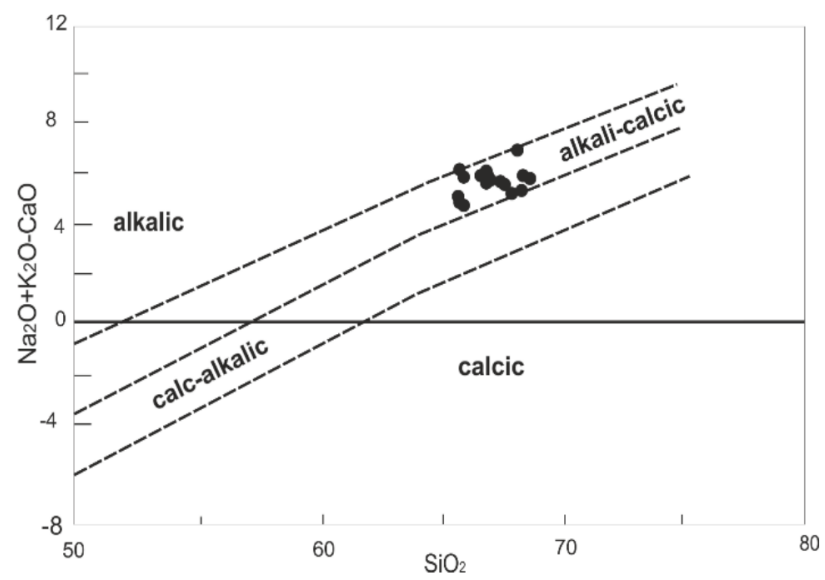

Рис. 6. Составы гранодиоритов Луневского массива на классификационной диаграмме $\mathrm{Na}_{2} \mathrm{O}+\mathrm{K}_{2} \mathrm{O}-\mathrm{CaO}-\mathrm{SiO}_{2}$.

[Fig. 6. $\mathrm{Na}_{2} \mathrm{O}+\mathrm{K}_{2} \mathrm{O}-\mathrm{CaO}-\mathrm{SiO}_{2}$ diagram for granodiorites of the Lunevsky Massif.]

На классификационных диаграммах [16] гранодиориты Луневского массива попадают в поля железистых и магнезиальных метаглиноземистых пород известково-щелочной серии (рис. 5, 6). Из-за повышенной щелочности точки составов гранодиоритов попадают на классификационных диаграммах $[17,18]$ преимущественно в поля кварцевых монцонитов и монцограгнитов (рис. 7). На бинарных диаграммах прослеживается неявная отрицательная корреляция кремнезема с алюминием, фосфором и титаном (рис. 8).

Для гранодиоритов характерны низкие содержания «мафических» элементов: $\mathrm{Cr}$ (4-48 ppm, ср. 29 ppm) и Ni (7-11 ppm), повышенные - литофильных: Ва (10101553 ppm, cp. 1176 ppm), Sr (532-760 ppm, cp. 641 ppm), $\mathrm{Rb}$ (98-139 ppm, ср. 121 ppm) и невысокие - высокозарядных Zr (93-170 ppm, cp. 143 ppm), Nb (9-14 ppm, среднее $11 \mathrm{ppm}), \mathrm{Y}(3.7-9.3 \mathrm{ppm})$ с очень высоким 
отношением $\mathrm{Sr} / \mathrm{Y}=65-168$. Гранодиориты характеризуются невысокими концентрациями редкоземельных элементов ( $\mathrm{REE}=66-131 \mathrm{ppm}$, среднее $102 \mathrm{ppm}) \mathrm{c}$ обогащением LREE $[(\mathrm{La} / \mathrm{Yb}) \mathrm{n}=16.1-42.9]$ и умеренным их фракционированием [(La/Sm)n = 4.4-7.7] (табл. 1, рис. 9 а). Спектры распределения Р3Э, нормированные к хондриту [19], имеют отрицательный наклон в области LREE и довольно пологий для HREE (рис. 9 a). Выраженная Еu аномалия отсутствует $\left(\mathrm{Eu} / \mathrm{Eu}^{*}=0.84-1.37\right)$. На мультиэлементной спайдердиаграмме, нормализованной к составу примитивной мантии [20], все образцы обнаруживают положительный пик $\mathrm{Pb}$, отрицательные аномалии $\mathrm{Nb}$, слабо отрицательные Р и Ті (рис. 9 b).
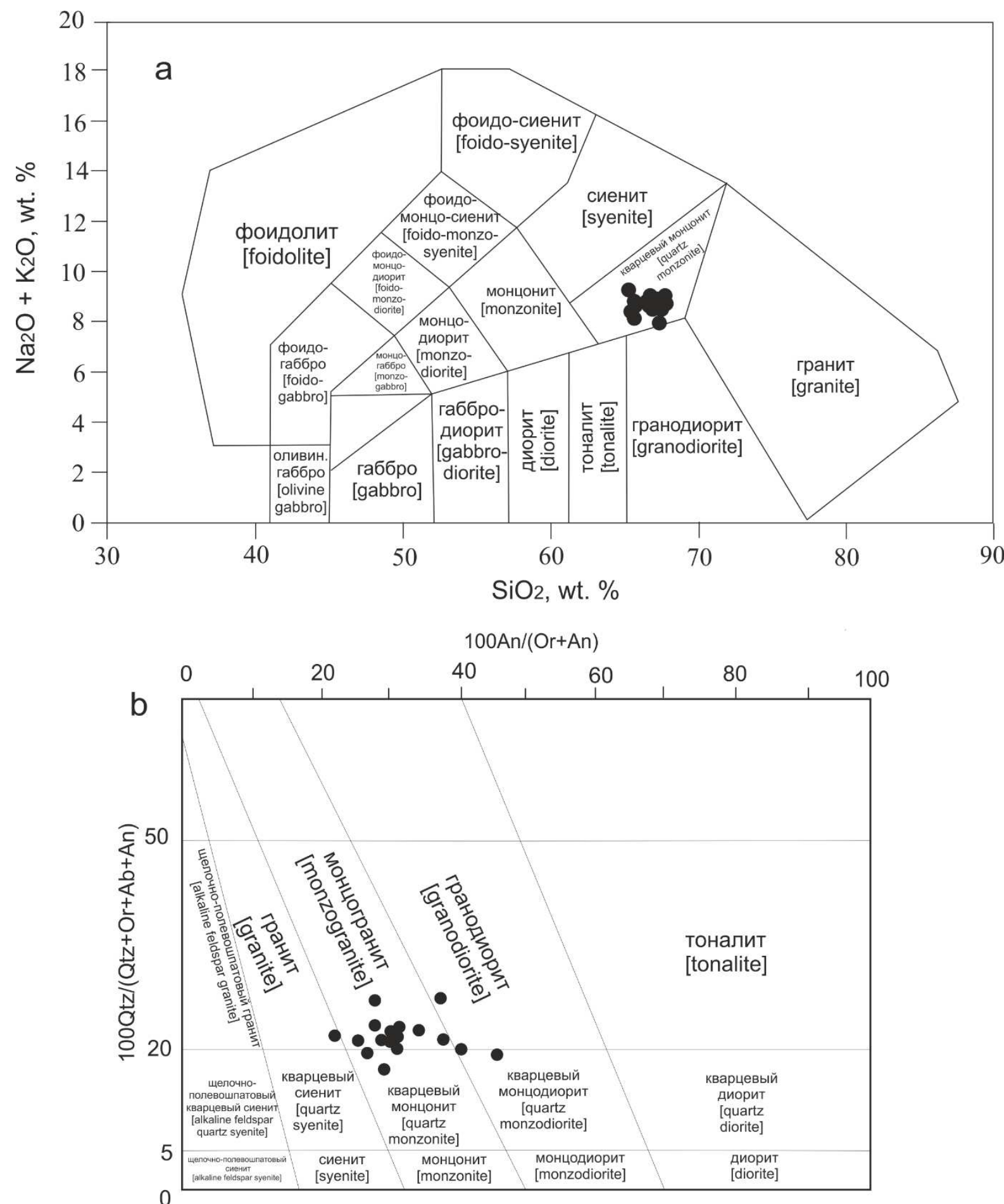

Рис. 7. Составы гранодиоритов Луневского массива на классификационных диаграммах: a) $\mathrm{Na}_{2} \mathrm{O}+\mathrm{K}_{2} \mathrm{O}-\mathrm{SiO}_{2}$ [17]; $b$ ) 100An/(Or+An) - 100Qtz/(Qtz+Or+Ab+An) [18].

[Fig. 7. Classification diagrams for granodiorites of the Lunevsky Massif: a) $\mathrm{Na}_{2} \mathrm{O}+\mathrm{K}_{2} \mathrm{O}-\mathrm{SiO}_{2}$ [17]; b) 100An/(Or+An) 100Qtz/(Qtz+Or+Ab+An) [18].] 

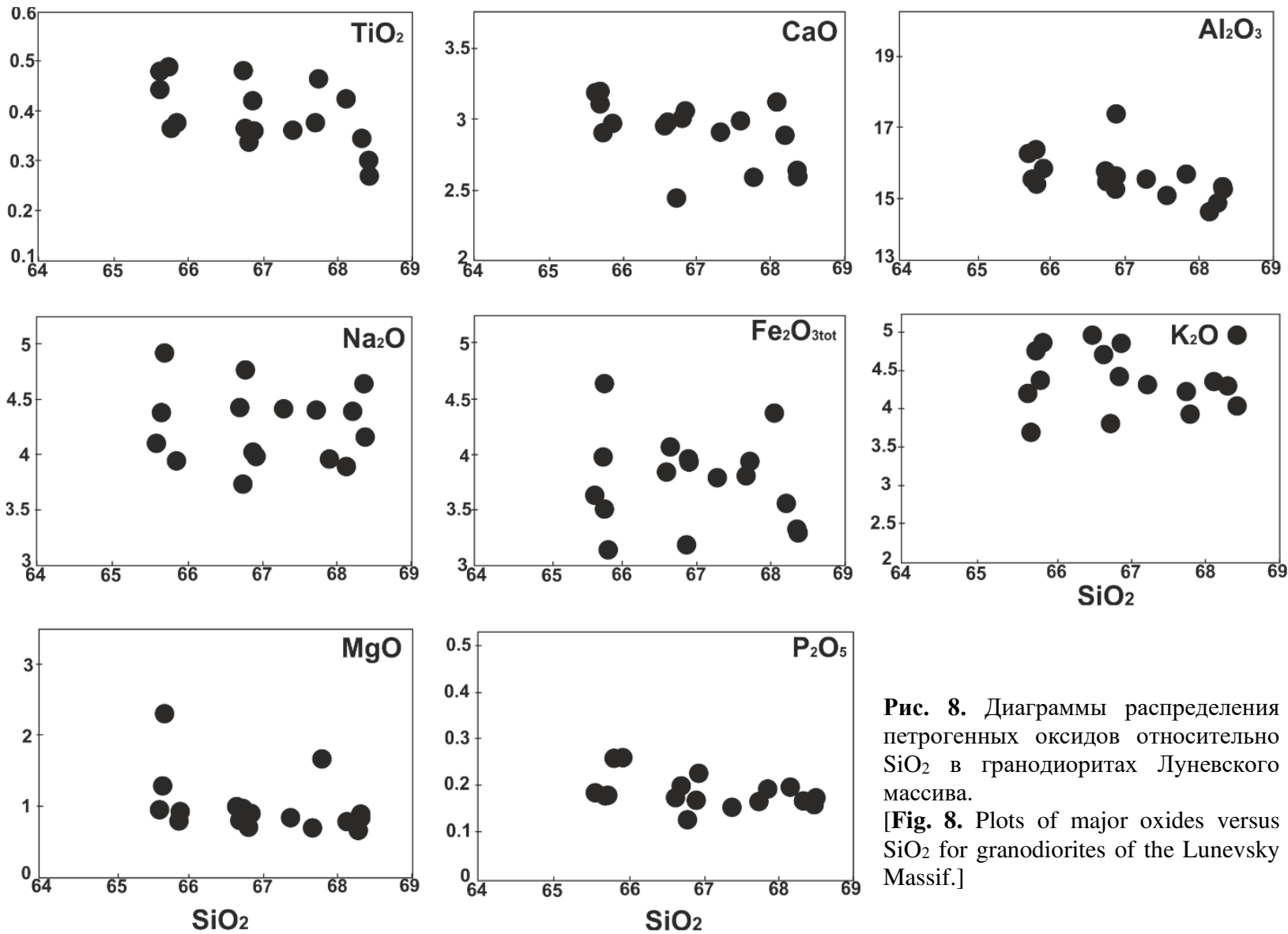

Рис. 8. Диаграммы распределения петрогенных оксидов относительно $\mathrm{SiO}_{2}$ в гранодиоритах Луневского массива.

[Fig. 8. Plots of major oxides versus $\mathrm{SiO}_{2}$ for granodiorites of the Lunevsky Massif.]
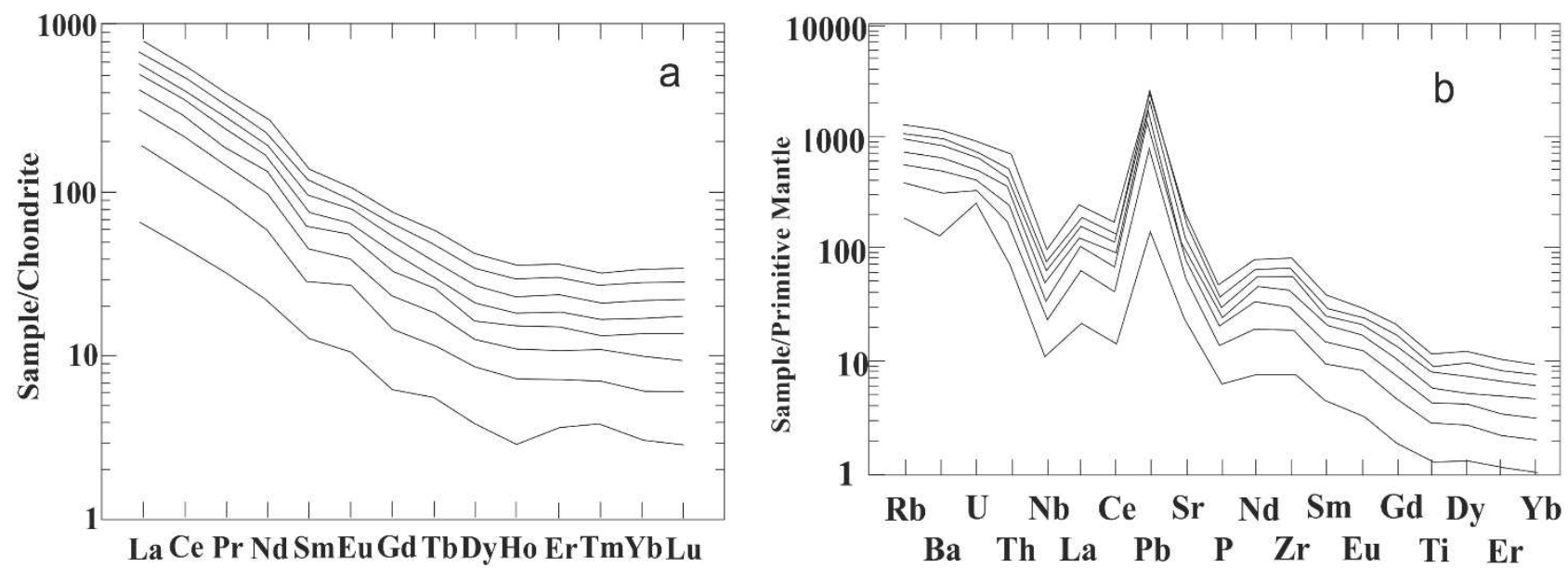

Рис. 9. Нормализованное к хондриту распределение редкоземельных (а) и нормализованное к примитивной мантии распределение малых и редких (b) элементов в гранодиоритах Луневского массива (данные по валовому составу пород).

[Fig. 9. Chondrite-normalized REE patterns (a) and Primitive mantle-normalized multi-element patterns (b) for the Lunevsky Massif granodiorites (data are for bulk-rock samples).]

\section{U-Pb геохронология}

Нами были выполнены определения возраста циркона на ионном микрозонде SHRIMP-II для пробы гранодиоритов 4006/252.5 (скважина 4006, глубина 252.5). Циркон рыже-коричневого цвета, полупрозрачный, представлен идиоморфными и субидиоморфными призматическими полупрозрачными кристаллами светло коричневой окраски, размером 80200 мкм с коэффициентом удлинения 1.5-4.0 (рис. 10). Присутствуют многочисленные твердофазные включения. В катодолюминесценции видна структура роста - тонкая концентрическая осцилляторная зональность. Явных унаследованных ядер не выявлено. Структурные и морфологические признаки указывают на магматическую природу циркона и практическое отсутствие значительных наложенных событий. Содержание $\mathrm{U}=156-904, \mathrm{Th}=63-540, \mathrm{Th} / \mathrm{U}$ $=0.25-0.77$. 


\begin{tabular}{|c|c|c|c|c|c|c|c|c|c|c|c|c|c|c|c|c|c|c|c|c|c|c|c|c|c|c|c|c|c|c|}
\hline 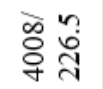 & $\stackrel{\infty}{-}$ & $\begin{array}{l}\text { ț } \\
\text { ¿ें }\end{array}$ & J. & 总 & $\begin{array}{c}n \\
\text { nn } \\
n\end{array}$ & $\stackrel{\text { ŏ }}{0}$ & 管 & भे & 望 & $\vec{\sim}$ & $\begin{array}{l}\infty \\
\stackrel{\infty}{0}\end{array}$ & $\stackrel{n}{=}$ & $\begin{array}{l}\text { के } \\
\stackrel{\text { a }}{ }\end{array}$ & c. & 志 & $\begin{array}{l}\text { c్ } \\
\text { ç }\end{array}$ & 气̊. & : & & & & & & & & & & & & \\
\hline 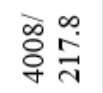 & 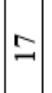 & $\begin{array}{l}0 \\
2 \\
\vdots \\
6\end{array}$ & f̊ & 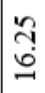 & $\stackrel{\check{m}}{\sigma}$ & तે & : & $\overrightarrow{\tilde{N}}$ & $\begin{array}{l}\stackrel{P}{2} \\
\stackrel{m}{*}\end{array}$ & 文 & 잉. & 完罗 & $\frac{7}{a}$ & ?ֶ. & $\begin{array}{c}m \\
\infty \\
\vdots\end{array}$ & 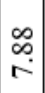 & à. & ঃ & & is & $\stackrel{0}{+}$ & & 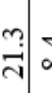 & & & in & $\vec{\Xi}$ & & & $\vec{a}$ \\
\hline ఫ্ণ & $ㅇ$ & 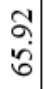 & $\begin{array}{l}0 \\
0 \\
0 \\
0\end{array}$ & $\begin{array}{l}\infty \\
\vdots \\
\vdots \\
n \\
-1\end{array}$ & $\stackrel{F}{F}$ & $\stackrel{\text { }}{\circ}$ & : & @. & $\begin{array}{c}\sigma \\
\tilde{m}\end{array}$ & $\begin{array}{c}\stackrel{c}{o} \\
\stackrel{+}{+}\end{array}$ & ஸุ & ô. & $\begin{array}{l}\infty \\
\infty \\
\alpha\end{array}$ & $\vec{m}$ & $\stackrel{\overbrace{}}{\rightarrow}$ & $\begin{array}{c}\stackrel{+}{d} \\
\dot{\infty}\end{array}$ & $\begin{array}{l} \pm \\
\vdots \\
\vdots\end{array}$ & হ & & & & & & & & & & & & \\
\hline ఫ্రి & $\therefore$ & $\begin{array}{l}2 \\
\hat{\sigma} \\
\hat{\sigma}\end{array}$ & 官 & $\begin{array}{l}\vec{b} \\
\ddot{n}\end{array}$ & $\begin{array}{l}\infty \\
\infty \\
m\end{array}$ & . & $\mid \begin{array}{l}2 \\
0 \\
0\end{array}$ & in & $\left|\begin{array}{l}\hat{\alpha} \\
\dot{m}\end{array}\right|$ & 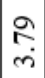 & $=$ & 它范 & $\begin{array}{l}n \\
2\end{array}$ & ?. & $\begin{array}{l}2 \\
\check{o}\end{array}$ & $\begin{array}{l}2 \\
\stackrel{2}{2}\end{array}$ & کૃّ & ஃ̆ & & $\stackrel{m}{i}$ & $\stackrel{\dot{m}}{.}$ & 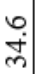 & : & & & 点 & $\stackrel{?}{ \pm}$ & & & a \\
\hline চे & \pm & $\begin{array}{l}\hat{2} \\
\text { b. }\end{array}$ & g. & $\begin{array}{l}m \\
m \\
n \\
n \\
-1\end{array}$ & $\begin{array}{l}\stackrel{8}{0} \\
\dot{\sim}\end{array}$ & $\stackrel{\infty}{=}$ & i. & 号 & $\begin{array}{c}m \\
m \\
m\end{array}$ & $\underset{f}{\stackrel{f}{f}}$ & ầ & \&̊. & & $\begin{array}{c}\tilde{c} \\
\grave{0}\end{array}$ & $\stackrel{\mathcal{g}}{-}$ & $\left.\mid \begin{array}{l}n \\
0 \\
\infty \\
\infty\end{array}\right]$ & ֵֵ. & ? & & & & & & & & & & & & \\
\hline 安 & $\rightarrow$ & 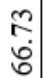 & f̊. & 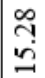 & $\begin{array}{l}\dot{d} \\
\dot{f}\end{array}$ & $\underset{-}{-}$ & : & ळे & $\left|\begin{array}{c}: \\
\hdashline \\
\dot{r}\end{array}\right|$ & $\mid \begin{array}{l}\vec{b} \\
\dot{+}\end{array}$ & ণุ| & $\begin{array}{l}\circ \\
:\end{array}$ & $\begin{array}{l}\vec{\infty} \\
\stackrel{\alpha}{\alpha}\end{array}$ & $\hat{\overbrace{}}$ & 空 & 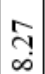 & ֻ̊. & 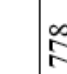 & & & & & & & & & & & & \\
\hline 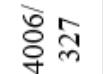 & $\approx$ & 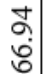 & fี & 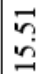 & $\mid \begin{array}{c}\infty \\
\infty \\
\dot{m}\end{array}$ & ț & : & @ & ळे & 桀 & สุ. & 吕 & $\begin{array}{l}\text { @ } \\
\stackrel{8}{\circ}\end{array}$ & $\hat{\overbrace{}}$ & $\underset{7}{-7}$ & $\begin{array}{c}J \\
\dot{\infty} \\
\infty\end{array} \mid$ & $\begin{array}{c}\tilde{o} \\
0\end{array}$ & ñ & & & & & & & & & & & & \\
\hline 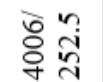 & $\Rightarrow$ & $\begin{array}{l}0 \\
0 \\
0 \\
0\end{array} \mid$ & $m$ & $\begin{array}{l}\stackrel{\infty}{\infty} \\
\stackrel{\Xi}{=}\end{array}$ & $\stackrel{\Rightarrow}{m}$ & $\underset{-}{\stackrel{8}{-}}$ & $\mid \begin{array}{l}t \\
0 \\
0\end{array}$ & $\stackrel{m}{n}$ & $\mid \begin{array}{l}\stackrel{P}{2} \\
\stackrel{f}{q}\end{array}$ & $\mid \begin{array}{c}\sigma \\
\dot{\sigma} \\
\dot{m}\end{array}$ & $\begin{array}{c}\overrightarrow{1} \\
0\end{array}$ & กิ่ & $\begin{array}{l}3 \\
0 \\
\circ\end{array}$ & $\begin{array}{c}\infty \\
\stackrel{0}{0} \\
0\end{array}$ & $\begin{array}{l}\stackrel{0}{2} \\
\vdots \\
0\end{array}$ & $\left.\begin{array}{c}\infty \\
m \\
\infty \\
\infty\end{array}\right]$ & $\exists$ & ڤั) & & $\stackrel{\circ}{i}$ & $\stackrel{\mathcal{T}}{\mathrm{f}}$ & m. & 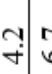 & & & $\stackrel{+}{i}$ & : & & & $\stackrel{m}{a}$ \\
\hline 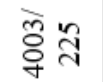 & 의 & 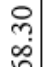 & m. & $\stackrel{9}{\circ}$ & مَ & : & : & $\vec{i}$ & 户্ & $\begin{array}{l}\vec{j} \\
\dot{m} \\
\dot{v}\end{array}$ & \begin{tabular}{c}
3 \\
\hdashline \\
0
\end{tabular} & ติ & 응 & ஸุ. & . & $\left.\mid \begin{array}{l}\infty \\
0 \\
\infty \\
\infty\end{array}\right]$ & 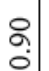 & ถู̆ & & & ల్c. & & $\overrightarrow{\text { a. }}$ & $\frac{9}{n}$ & & & : & & & $\vec{r}$ \\
\hline రิષે & a & $\left.\mid \begin{array}{l}n \\
0 \\
0 \\
0\end{array}\right]$ & I. & $\underset{\dot{f}}{F}$ & 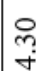 & $\begin{array}{l}R \\
i \\
0\end{array}$ & $\stackrel{0}{\circ}$ & $\stackrel{m}{m}$ & $\mid$ & $\begin{array}{c}m \\
m \\
\rightarrow\end{array}$ & $\stackrel{7}{3}$ & ঙ্ & $\begin{array}{l}\stackrel{2}{0} \\
\alpha\end{array}$ & הุ. & $\stackrel{m}{=}$ & 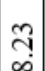 & 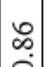 & i & & & & & & & & & & & & \\
\hline 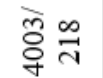 & $\infty$ & $\begin{array}{l}\hat{b} \\
\dot{0}\end{array}$ & ñ. & $\begin{array}{l}0 \\
-1 \\
\end{array}$ & 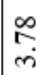 & F & 望 & à & 户্ & $\underset{\forall}{\vec{\gamma}}$ & 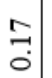 & ల్ & $\begin{array}{l}\infty \\
\stackrel{0}{0}\end{array}$ & ָิ) & $\begin{array}{l} \pm \\
\vdots \\
0\end{array}$ & {$\left[\begin{array}{l}0 \\
0 \\
\infty \\
\infty \\
\end{array}\right]$} & $\begin{array}{c}0 \\
\vdots \\
\vdots\end{array}$ & 太心 & & તิ่ & $\begin{array}{l}7 \\
i \\
i\end{array}$ & $\begin{array}{l}\infty \\
\dot{f} \\
\dot{f}\end{array}$ & 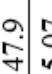 & & & $n$ & $\stackrel{\infty}{\Xi}$ & & & กี \\
\hline 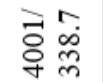 & r & $\begin{array}{l}1 \\
\hat{o} \\
0\end{array}$ & m. & 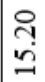 & ஓ & : & $\stackrel{\circ}{\circ}$ & $\stackrel{m}{\text { r. }}$ & $\mid \begin{array}{l}\mid r \\
o \\
\dot{r}\end{array}$ & 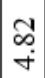 & ㄴ. & 号 & 홍 & 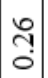 & $\stackrel{9}{7}$ & $\left.\begin{array}{c}\widehat{\omega} \\
\infty \\
\infty\end{array}\right]$ & {$\left[\begin{array}{c}\infty \\
\infty \\
0 \\
0\end{array}\right]$} & : & & & & & & & & & & & & \\
\hline ठें & 0 & \begin{tabular}{l}
2 \\
\multirow{3}{6}{}
\end{tabular} & 离 & $\begin{array}{l}\stackrel{9}{9} \\
\stackrel{0}{0}\end{array}$ & ñ & $\vec{r}$ & in & 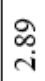 & $\left|\begin{array}{c}\infty \\
\infty \\
+ \\
+\end{array}\right|$ & 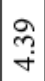 & $\begin{array}{l}0 \\
0 \\
0 \\
0\end{array}$ & 苦 & ஃั & ָุे & $\begin{array}{l}\stackrel{1}{0} \\
\vdots\end{array}$ & तે & $\vec{a}$ & : : & & 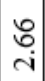 & : & rn & 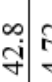 & 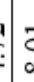 & & $\overrightarrow{5}$ & $\begin{array}{l}\infty \\
\infty \\
\infty\end{array}$ & & & 离 \\
\hline 호요 & n & $\begin{array}{l}\overrightarrow{7} \\
\dot{0} \\
0\end{array}$ & : & 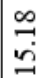 & 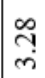 & $\vec{E}$ & $\begin{array}{l}t \\
0 \\
0\end{array}$ & 总 & $\left|\begin{array}{c}n \\
n \\
q \\
q\end{array}\right|$ & $\stackrel{\tilde{m}}{\tilde{m}}$ & $\stackrel{0}{\circ}$ & ?̊ & ¿̊. & $\begin{array}{l}0 \\
\vdots \\
0 \\
0\end{array}$ & $\begin{array}{c}0 \\
0 \\
0 \\
0\end{array}$ & {$\left[\begin{array}{c}0 \\
\omega \\
\infty \\
\infty\end{array}\right]$} & 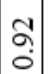 & 俈 & & & & & & & & & & & & \\
\hline 客等 & + & $\begin{array}{l}8 \\
0 \\
0 \\
0\end{array}$ & 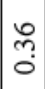 & $\begin{array}{l}\infty \\
n \\
n \\
n \\
n\end{array}$ & $\stackrel{\Re}{r}$ & 点 & i̊ & ळे & $\underset{F}{\vec{F}}$ & in & $\stackrel{7}{0}$ & @্ & กे & 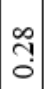 & 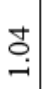 & 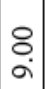 & $\left.\begin{array}{c}\infty \\
\infty \\
0 \\
0\end{array}\right]$ & ஙૂ & & $\vec{a}$ & & m & $\begin{array}{lll}0 \\
\text { mas }\end{array}$ & 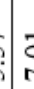 & & 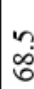 & 2 & & & 总 \\
\hline 官 & $m$ & 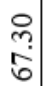 & $\begin{array}{l}m \\
m \\
0\end{array}$ & 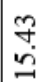 & $\vec{r}$ & E. & in & $\begin{array}{c}\hat{\infty} \\
\text { i } \\
\text { in }\end{array}$ & $\underset{f}{\stackrel{f}{+}}$ & \begin{tabular}{|l}
$\stackrel{p}{m}$ \\
$\stackrel{m}{+}$
\end{tabular} & $\frac{2}{0}$ & ஸึ & ڤે & ç & $\begin{array}{l}\hat{a} \\
\text { o. }\end{array}$ & $\underset{\infty}{\stackrel{2}{\infty}}$ & @. & 용 & & & & & & & & & & & & \\
\hline ఫેઠ & N & $\begin{array}{l}7 \\
7 \\
0 \\
0\end{array}$ & 品 & 合 & ते & $\begin{array}{l}R \\
0 \\
0\end{array}$ & in & 点 & $\stackrel{\mathcal{I}}{+}$ & $\mid \begin{array}{c}\infty \\
\infty \\
+\end{array}$ & $\stackrel{2}{0}$ & ?f & $\begin{array}{l}\text { ळे } \\
\text { ूे }\end{array}$ & 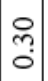 & $\stackrel{\infty}{\exists}$ & \begin{tabular}{l}
8 \\
\hdashline \\
\end{tabular} & ô. & ঃั & & $\vec{i}$ & $\stackrel{\text { o. }}{\text { i }}$ & : & ले & & & "n & $\stackrel{3}{=}$ & & กิ & $\begin{array}{c}\infty \\
\dot{\infty} \\
i\end{array}$ \\
\hline 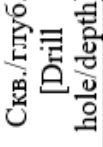 & & & & ○్ & 离 & 盛 & & ర & $\begin{array}{l}\text { O } \\
\text { జ̇ }\end{array}$ & O & & 目完 & 學 & and & 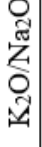 & 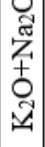 & | & $\begin{array}{c}0 \\
0 \\
\text { D. } \\
\text { H. }\end{array}$ & & - & & & & & & & & & & 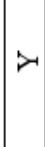 \\
\hline
\end{tabular}




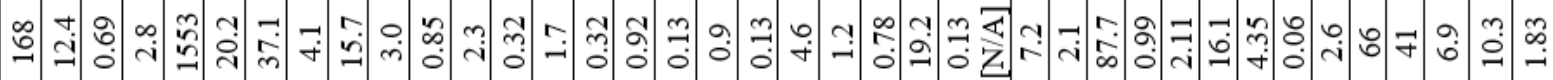
जิ

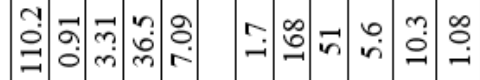

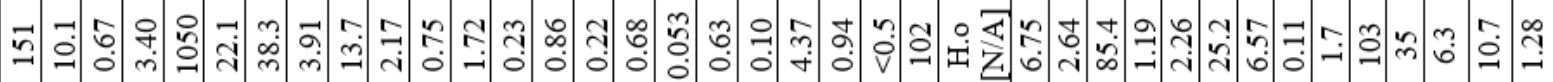

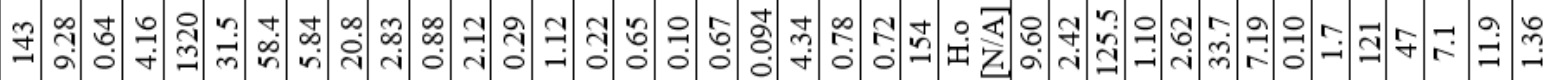

‡ิ n̊:

๙ૅ:

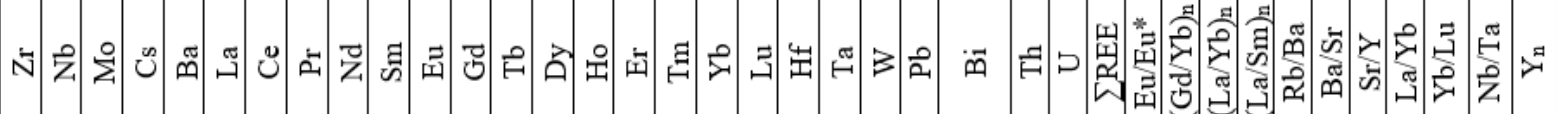



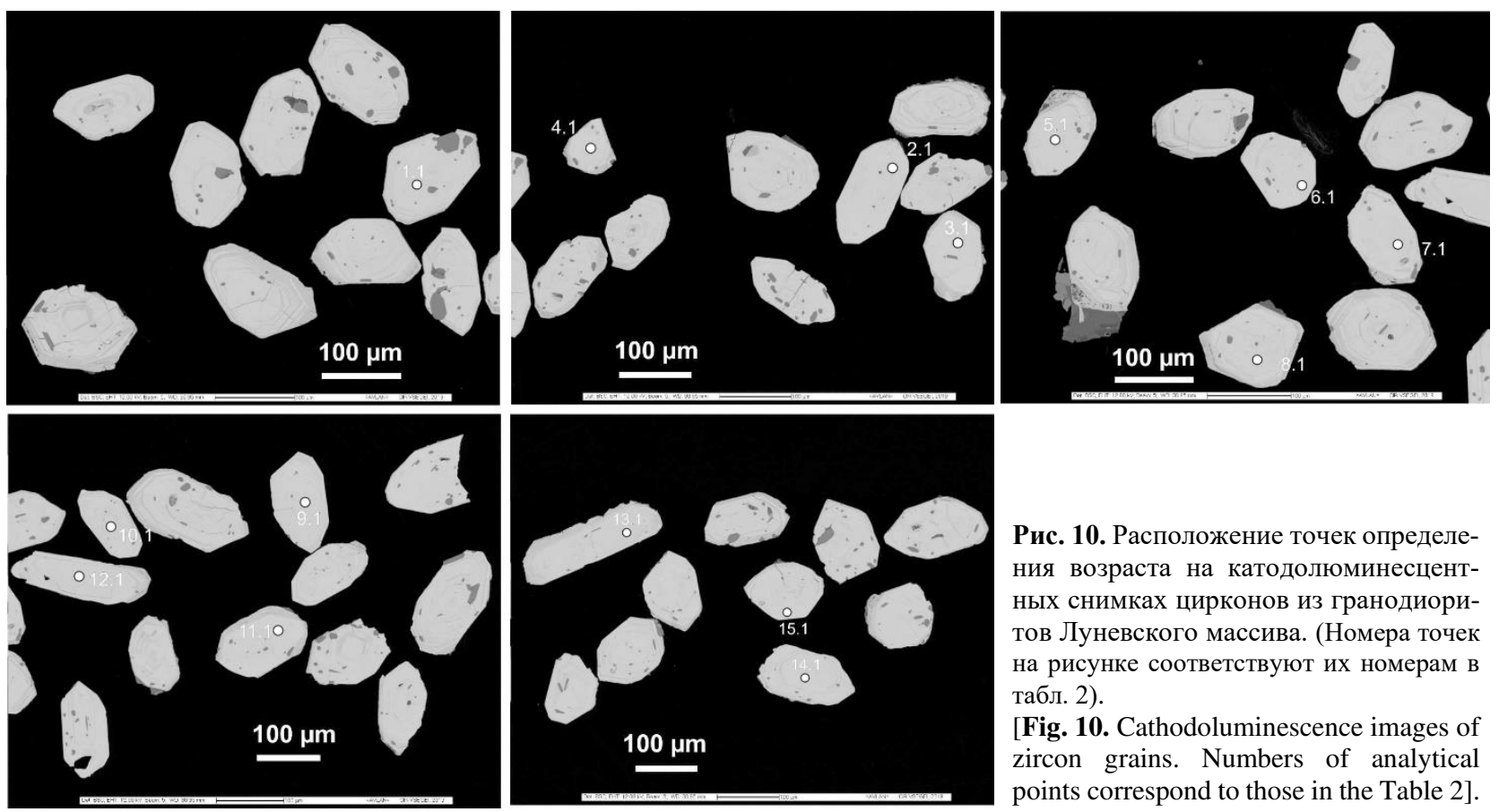

Рис. 10. Расположение точек определения возраста на катодолюминесцентных снимках цирконов из гранодиоритов Луневского массива. (Номера точек на рисунке соответствуют их номерам в табл. 2).

[Fig. 10. Cathodoluminescence images of zircon grains. Numbers of analytical points correspond to those in the Table 2].
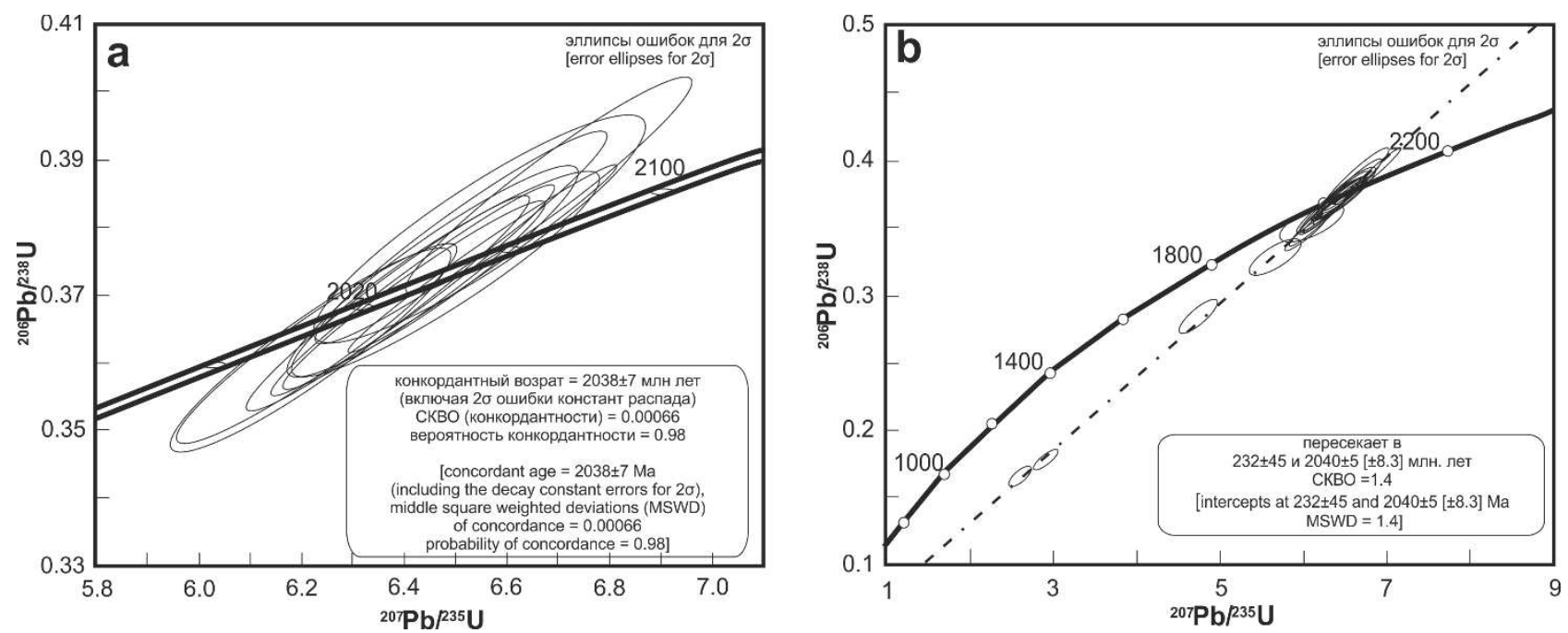

Рис. 11. Результаты U-Pb датирования цирконов из гранитов гранодиоритов Луневского массива методом SIMS.

[Fig. 11. The results of U-Pb SIMS analyses of zircons from granodiorites of the Lunevsky Massif.]

Было выполнено 20 анализов в 18 зернах (рис. 10, табл. 2). Все результаты на графике с конкордией аппроксимируются единой линией регрессии (рис. $11 \mathrm{a}$ ). Невысокая девиация точек от линии регрессии $(\mathrm{CKBO}=1.4)$ предполагает минимальные воздействие докембрийских процессов на данные цирконы. Возраст по верхнему пересечению с конкордией (20 анализов) составляет $2040 \pm 5$ млн лет. Значения, полученные по нижним пересечениям дискордии, учитывая сложную историю пород, вероятнее всего не имеют геологического смысла. Этот возраст совпадает с рассчитанным конкордантным возрастом 2038 \pm 7 млн лет $(11$ анализов, СКВО $=0.00066$; вероятность конкордантности 0.98) (рис. 11 b).

\section{Lu-Hf и Sm-Nd изотопная систематика}

Изотопный состав Hf был определен в цирконе из образца 4006/252.5 и анализировался в тех же точках, где измерялся U-Pb изотопный возраст. В отличие от $\mathrm{U}-\mathrm{Pb}$ изотопной системы, которая во всех зернах циркона имеет близкий возраст, Lu-Hf изотопная система в тех же зернах демонстрирует широкие вариации изотопного состава гафния при расчете на этот возраст $\left(\varepsilon \mathrm{Hf}_{(2040)}\right.$ от -2.0 до -12.4) (табл. 3, рис. 12). Модельные возрасты $\mathrm{T}_{\mathrm{Hf}}(\mathrm{C})$, рассчитанные по двухстадийной модели, варьируют от 2794 до 3429 млн лет. Среди них преобладают модельные возрасты, предполагающие довольно длительную коровую предысторию их протолитов (рис. 12). 


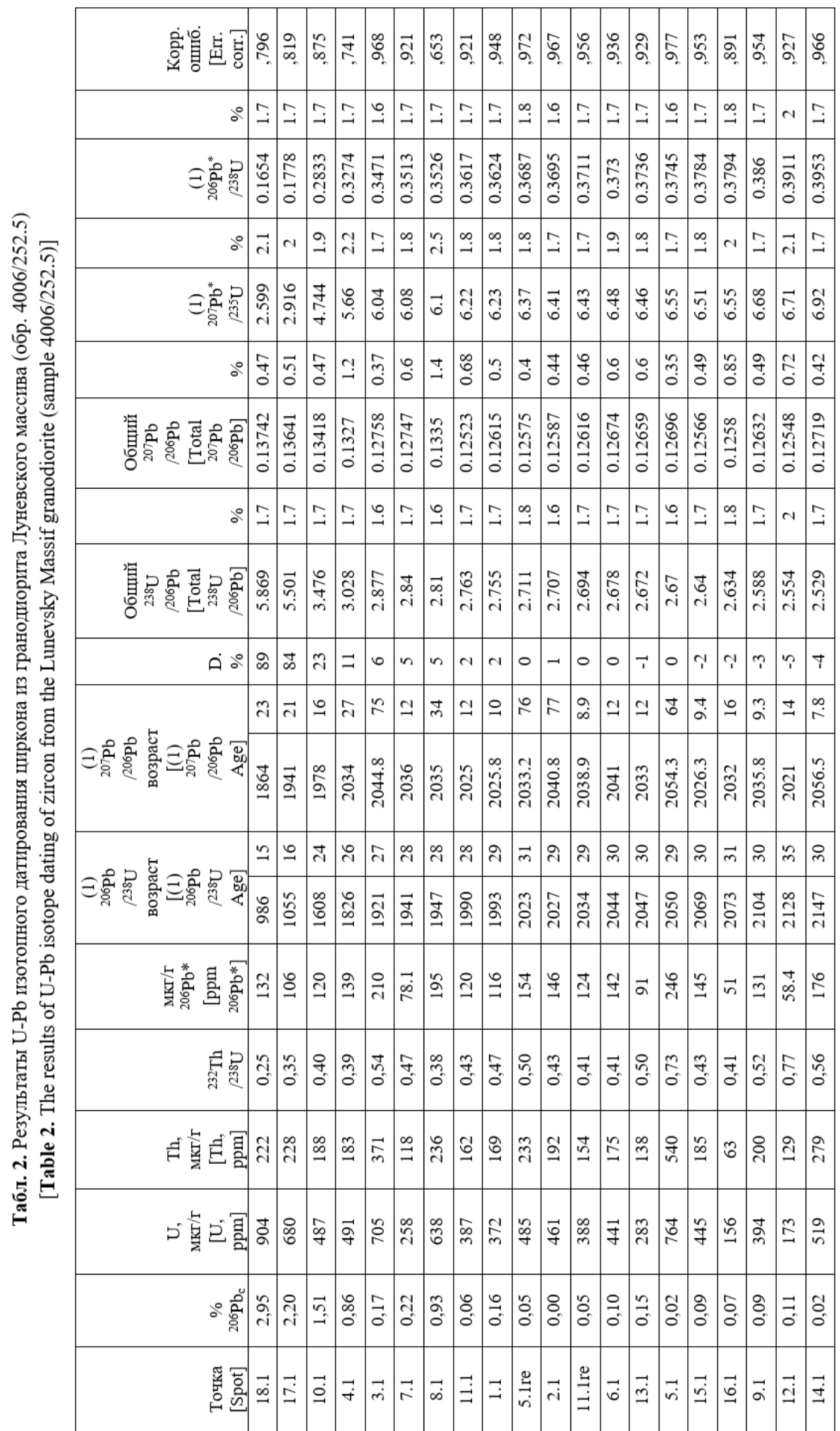




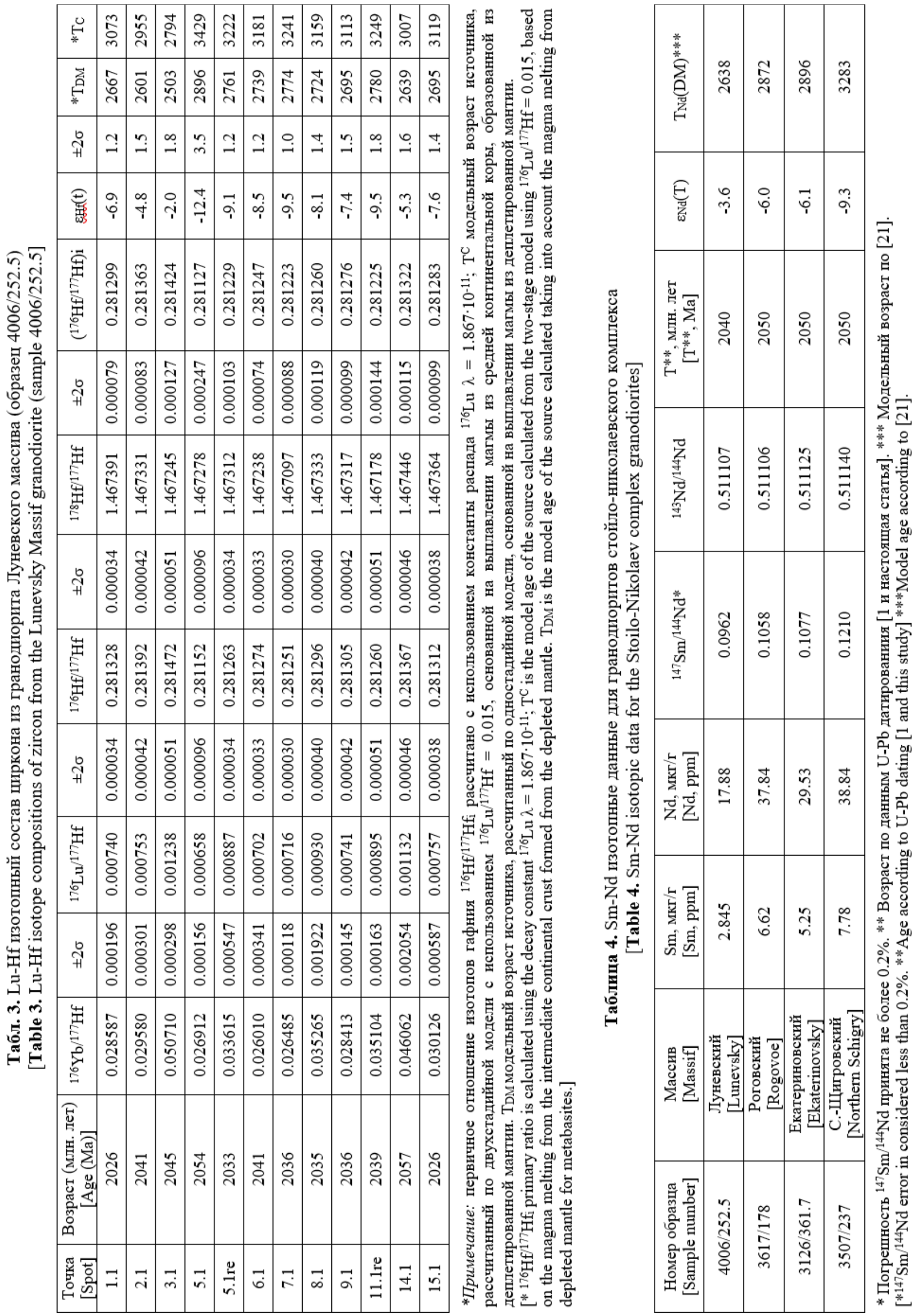




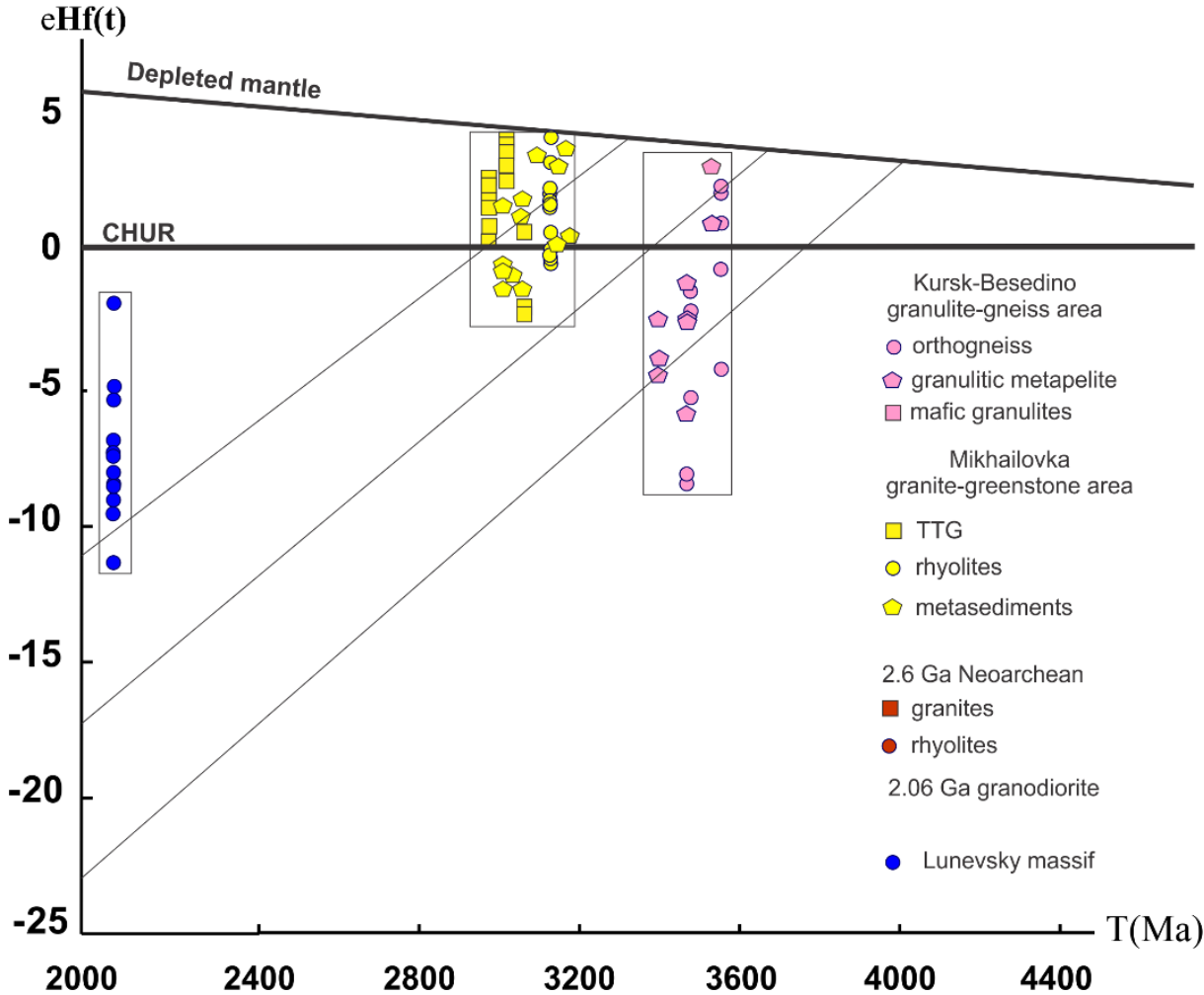

Рис. 12. Диаграмма $\varepsilon \mathrm{Hf}(\mathrm{t})-\mathrm{T}$ для циркона из гранодиоритов Луневского массива.

[Fig. 12. Plots of $\varepsilon \mathrm{Hf}(\mathrm{t})$ values versus zircon ages for zircon grains from granodiorites of the Lunevsky Massif.]
Изотопный состав $\mathrm{Nd}$ был измерен в валовой пробе того же гранодиорита 4006/252.5. Значение $\varepsilon \mathrm{Nd}(2040)$ составляет (-3.6), а модельный возраст $\mathrm{TNd}(\mathrm{DM})=$ 2638 млн лет (табл. 4).

\section{Обсуждение результатов \\ Геохимическая типизация}

По минеральному составу и геохимическим характеристикам гранодиориты Луневского массива принадлежат к гранитоидам I-типа, которые по геохимии близки к породам вулканических дуг. Массив сложен только биотитовыми гранодиоритами, в них отсутствует мусковит и сопровождающие интрузию пегматитовые тела. Они являются в основном метаглиноземистыми, железисто-магнезиальными (рис. 4, 5) и, несмотря на высокое содержание щелочей, имеют близкие концентрации калия и натрия. Породы относятся к известковощелочной серии (рис. 6), обогащены литофильными элементами $\mathrm{Rb}, \mathrm{Ba}, \mathrm{Sr}$, обеднены РЗЭ и высокозарядными элементами. В них отсутствует выраженная европиевая аномалия (рис. 9 а), но есть сильная положительная аномалия Рb и отрицательная - Тi (рис. 9 b). Эти признаки характерны для гранитов I-типа [22] и отличают их от калиевых, перглиноземистых мусковитовых гранитов S-типа и высоко железистых, обогащенных РЗЭ и высокозарядными элементами гранитов А-типа. Кроме того, для гранитов A- и S-типов характерны отрицательные $\mathrm{Eu}$ аномалии. Спецификой гранодиоритов I-типа Луневского массива являются высокие содержания щелочей и низкие - «мафических элементов» $\mathrm{Cr}$ и $\mathrm{Ni}$.

На дискриминантных диаграммах для выделения гранитов А-типа $\left(\mathrm{Na}_{2} \mathrm{O}+\mathrm{K}_{2} \mathrm{O}\right) / \mathrm{CaO}-\mathrm{Zr}-\mathrm{Nb}-\mathrm{Ce}-\mathrm{Y}, \mathrm{Ce}-$ $\mathrm{Zr}$ и $\mathrm{FeO}_{\mathrm{t}} / \mathrm{MgO}$ - $\mathrm{Zr}-\mathrm{Nb}-\mathrm{Ce}-\mathrm{Y}$ [23] точки составов гранодиоритов Луневского массива попадают в объединенные поля гранитов I, S и М типов (рис. 13, 14). Кроме того, такие геохимические характеристики, как высокие содержания $\mathrm{Al}_{2} \mathrm{O}_{3}$ ( $\geq 15$ мас. \%), Sr (ср. 640 ppm), низкие содержания Y (<10 ppm) и HREE, а также отсутствие Еu* аномалий сближает их с гранитоидами адакитовых серий. На дискриминантных диаграммах $[24,25]$ точки составов гранодиориотв ложатся в поля адакитов (рис. 15).

\section{Р-Т условия кристаллизаиии магм}

Наиболее широко для оценки температуры гранитоидных магм используют термометрию по насыщению расплавов $\mathrm{Zr}$, основанную на результатах экспериментальных калибровок [26, 27, 28], поскольку циркон является одним из самых ранних кристаллизующихся минералов. В целом для метаглиноземистых гранодиоритов І-типа Луневского массива применим этот метод, поскольку все цирконы являются ликвидусными фазами, образуют идиоморфные кристаллы и не содержат унаследованных ядер, фиксируя возраст магматизма 2040 млн лет (рис. 10, 11). Температуры насыщения цирконием, условно принимаемые как минимальные ликвидусные, оказались очень высокими и находятся в интервале $906-986^{\circ} \mathrm{C}(\mathrm{n}=8)$, при среднем значении $966^{\circ} \mathrm{C}$ (табл. 1).

Кроме того, мы использовали недавно предложенный простой эмпирический термометр по оценке температур кристаллизации гранитоидов по содержанию $\mathrm{SiO}_{2}$ в породе, на основе экспериментально определенного фазового равновесия $\mathrm{T} \propto 1 / \mathrm{SiO}_{2}$ [29]. Температуры кристаллизации гранодиоритов составляют $754-794^{\circ} \mathrm{C}$ $(\mathrm{n}=17)$ (табл. 1). 

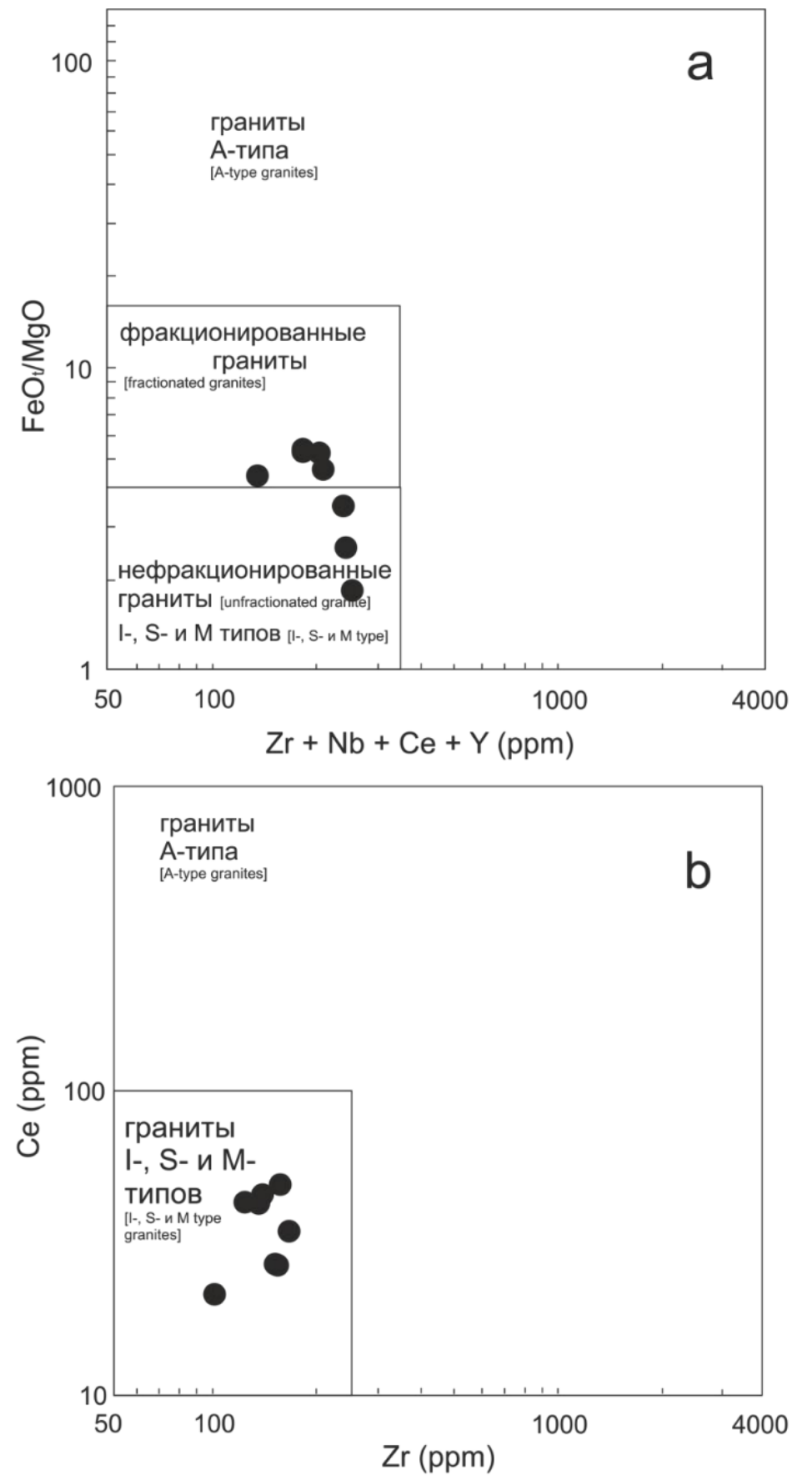

Рис. 13. Составы гранодиоритов Луневского массива на дискриминантных диаграммах $\mathrm{FeOt} / \mathrm{MgO}-\mathrm{Zr}-\mathrm{Nb}-\mathrm{Ce}-\mathrm{Y}$ и $\mathrm{Ce}-\mathrm{Zr}$ [23].

[Fig. 13. Discrimination diagrams FeOt/MgO - Zr-Nb-Ce-Y и Ce-Zr [23] for the granodiorites of the Lunevsky Massif.]

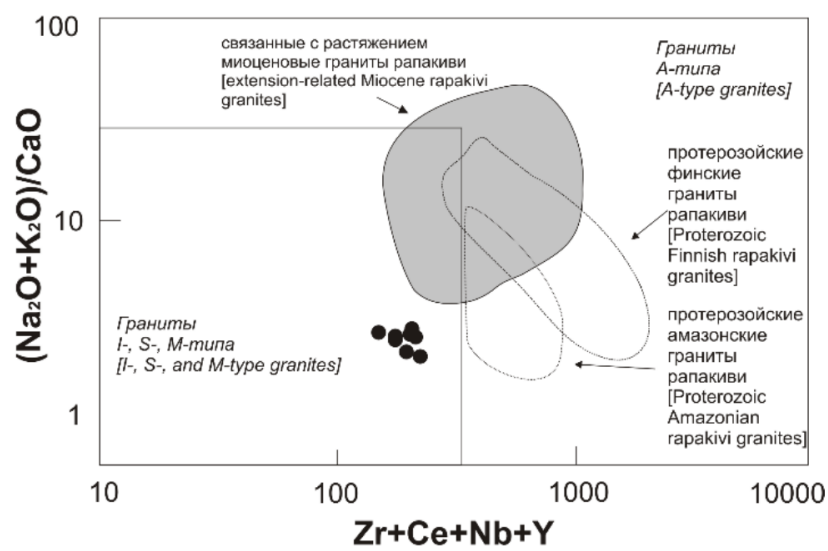

Рис. 14. Составы гранодиоритов Луневского массива на дискриминантной диаграмме $\left(\mathrm{Na}_{2} \mathrm{O}+\mathrm{K}_{2} \mathrm{O}\right) / \mathrm{CaO}-\mathrm{Zr}-\mathrm{Nb}-\mathrm{Ce}-\mathrm{Y}$ [23]. [Fig. 14. Discrimination diagram $\left(\mathrm{Na}_{2} \mathrm{O}+\mathrm{K}_{2} \mathrm{O}\right) / \mathrm{CaO}-\mathrm{Zr}-\mathrm{Nb}-$ $\mathrm{Ce}-\mathrm{Y}$ [23] for the granodiorites of the Lunevsky Massif.]
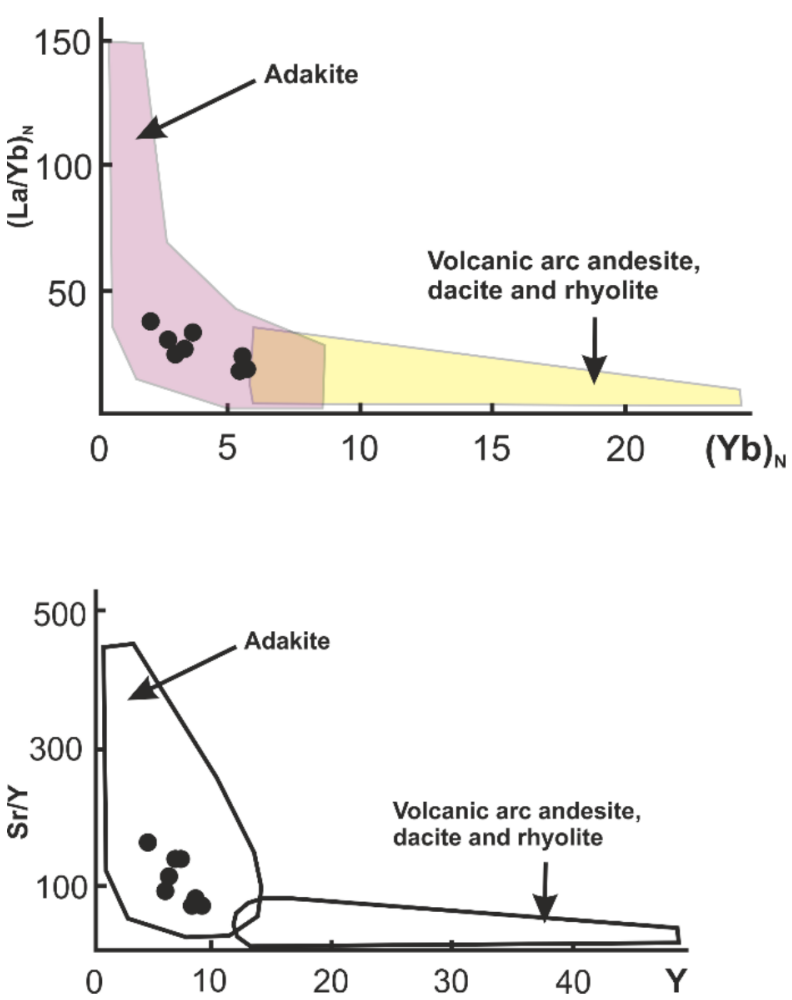

Рис. 15. Составы гранодиоритов Луневского массива на дискриминантных диаграммах для пород адакитовых серий.

[Fig. 15. Adakite discrimination diagrams $[24,25]$ for the granodiorites of the Lunevsky Massif.]

\section{Источники расплавов}

Lu-Hf изотопные анализы выявили широкие вариации изотопного состава гафния в отдельных зернах магматического циркона из гранодиорита (табл. 3, рис. 12). Это, возможно, отражает Lu-Hf гетерогенность среды кристаллизации цирконов, унаследованную от разных по составу и возрасту пород в корово-мантийном источнике. Широкий диапазон изотопного состава Нf и модельных возрастов (табл. 3), более радиогенный состав $\mathrm{Nd}$, чем в других массивах гранодиоритов в Тим-Ястребовской структуре (табл. 4) исключают механизм фракционной кристаллизации и контаминации (AFC) единого исходного расплава. К тому же, выплавление гранитоидов при фракционировании базальтовых расплавов сопровождалось бы удалением плагиоклаза с образованием отрицательных $\mathrm{Eu}^{*}$ аномалий и сильным обеднением Sr [30], чего не наблюдается в гранодиоритах Луневского массива. Поэтому мы полагаем, что существовало несколько независимых источников гранодиоритовых магм. Следовательно, в петрогенезисе гранодиоритов Луневского массива участвовало, как минимум два контрастных по изотопно-геохимическим характеристикам источника магм: палеоархейские коровые и палеопротерозойские мантийные субстраты. Палеоархейские ТТГ с возрастом 3.3-3.5 млрд лет [31] являются древним фундаментом для палеопротерозойских вулканогенно-осадочных толщ, выполняющих Тим-Ястребовскую внутриконтинентальную рифтогенную структуру и, несомненно, участвовали в петрогенезисе гранодиоритов, обеспе- 
чивая в них низкорадиогенную компоненту изотопного сотава Нf.

Другим источником являются палеопротерозойские мантийные расплавы, о чем прямо свидетельствуют диориты в других диорит-гранодиоритовых массивах (Роговский, Северощигровский) и интрузии габброидов в Тим-Ястребовской структуре. Ранее нами изучался петрогенезис андезитовых порфиритов (палеовулкан) с возрастом 2067 млн лет северо-западнее Тим-Ястребовской структуры, также имеющих адакитовые характеристики, но с двумя контрастными кластерами изотопного состава Нf (от $+3,3$ до $+6,8$ и от -12,7 до -13,3) [7, 32]. Был сделан вывод, что адакитовые сигнатуры порфиритов возникли в результате двухстадийного процесса ассимиляции коровых пород мантийным расплавом в основании деламинированной коры и кристаллизационной дифференциации базальтовых магм в верхнекоровых магматических камерах.

Гранодиориты I-типа занимают посттектоническую позицию. Их внедрением 2.04-2.07 млрд лет назад завершились субдукционные и коллизионные процессы в интервале 2.1-2.07 млрд лет. Гранодиориты Луневского массива находятся значительно ближе к границе архейского Курского блока и палеопротерозойского Волго-Донского орогена, чем андезитовые порфириты. Волго-Донской ороген сложен палеопротерозойскими ювенильными осадочно-вулканогенными и интрузивными комплексами [33]. Адакитовые геохимические характеристики гранодиоритов предполагают участие субдукционной компоненты во втором источнике. Отрыв субдуцируемой океанической плиты привел к образованию плитного окна (slabwindow), что инициировало апвеллинг астеносферной мантии и базальтовый магматизм с возрастом 2099 млн лет в Тим-Ястребовской структуре [34]. Таким образом, еще одним источником с ювенильными изотопными характеристиками могли быть мантийные магмы, возникшие при плавлении субдуцировавшей океанической литосферы Волго-Донского орогена под континентальную кору Курского блока.

\section{Выводы}

Гранодиориты Луневского массива в Тим-Ястребовской структуре являются метаглиноземистыми, железисто-магнезиальными породами известково-щелочной серии. Они обогащены литофильными и обеднены высокозарядными элементами и характеризуются сильно фракционированным распределением РЗЭ и отсутствием $\mathrm{Eu}$ аномалий. Наряду с этими признаками положительная аномалия $\mathrm{Pb}$ и отрицательная аномалия Ті позволяют отнести их к гранитоидам I-типа. Кроме того, в гранодиоритах установлены высокие значения отношений $\mathrm{La} / \mathrm{Yb}$ и $\mathrm{Sr} / \mathrm{Y}$, что сближает их с гранитоидами адакитовых серий.

Возраст кристаллизации Луневского гранодиоритового массива составляет 2040 млн лет. Он имеет посттектоническую позицию. Постколлизионным магматизмом 2.04-2.07 млрд лет назад завершились субдукционные и коллизионные процессы в интервале $2.1-$

\subsection{7 млрд лет.}

Изотопный состав Hf в цирконе указывает на участие в образовании гранодиоритового расплава нескольких источников, включающих коровые палеоархейские и ювенильные мантийные палеопротерозойские протолиты. Адакитовые характеристики гранодиоритов предполагают участие субдукционной компоненты во втором источнике. Ими могли быть (1) ТТГ, которые слагают древнее палеоархейское ядро Курского блока, и (2) мантийные магмы с ювенильными изотопными характеристиками, образовавшиеся при плавлении субдуцировавшей океанической литосферы Волго-Донского орогена.

Конфликт интересов: Авторы декларируют отсутствие явных и потенциальных конфликтов интересов, связанных с публикацией настоящей статьи.

\section{ЛИТЕРАТУРА}

1. Савко К. А., Самсонов А. В., Базиков Н. С., Козлова Е. Н. Палеопротерозойские гранитоиды Тим-Ястребовской структуры Воронежского кристаллического массива: геохимия, геохронология и источники расплавов // Вестник Воронежского государственного университета. Серия: Геология. 2014. № 2. C. 56-78.

2. Савко К. А., Самсонов А. В., Холин В. М., Базиков Н. С. Мегаблок Сарматия как осколок суперкратона Ваалбара: корреляция геологических событий на границе архея и палеопротерозоя // Стратиграфия. Геол. корреляция. 2017. Т. 25. № 2. C. 3-26. DOI: 10.7868/S0869592X17020065

3. Кориш Е. Х., Савко К. А., Самсонов А. В., Червяковская М. В. Палеопротерозойские диориты Троснянского массива Курского блока Сарматии: U-Pb возраст, изотопная систематика и источники расплавов// Вестник Воронежского государственного университета. Серия: Геология. 2020. № 1. С. 87-99. DOI: $10.17308 /$ geology.2020.1/2517

4. Цыбуляев С. В., Савко К. А., Кориш Е. Х., Червяковская М. В. Изотопно-геохимические особенности и геодинамическое положение пород щебекинского комплекса Курского блока восточной Сарматии // Петрология и геодинамика геологических прочессов: материалы XIII Всероссийского петрографического совещания (с участием зарубежных ученых). Иркутск, 6-13 сентября 2021. Т. 3. С. 196-198.

5. Альбеков А. Ю., Рыборак М. В., Бойко П. С. Реперное U$\mathrm{Pb}$ изотопное датирование палеопротерозойских габброидных формаций Курского блока Сарматии (Воронежский Кристаллический Массив) // Вестник Воронежского государственного университета. Серия: Геология. 2012. № 2. С. 84-94.

6. Цыбуляев С. В., Савко К. А. Геохимическая типизация палеопротерозойских вулканитов бимодальной серии курбакинской свиты Курского блока Восточной Сарматии // Becmник Воронежского государственного университета. Серия: Геология. 2017. № 1. С. 61-75.

7. Цыбуляев С. В., Савко К. А. U-Рb Изотопный возраст и тектоническая позиция палеопротерозойских андезитовых порфиритов Курского блока Восточной Сарматии // Вестник Воронежского государственного университета. Серия: Геология. 2018. № 3. С. 29-35. DOI: 10.17308/geology.2018.3/1559

8. Bogdanova S., Gorbatschev R., Grad M., Guterch A., Janik T., Kozlovskaya E., Motuza G., Skridlaite G., Starostenko V., Taran L. EUROBRIDGE: new insight into the geodynamic evolution of the East European Craton // European Lithosphere Dynamics. 
Eds.: Gee, D.G., Stephenson, R.A. Geol. Soc. London Mem. 2006. V. 32. P. 599-628. DOI: 10.1144/GSL.MEM.2006.032.01.36

9. Larionov A. N., Andreichev V. A., Gee D. G. The Vendian alkaline igneous suite of northern Timan: ion microprobe $\mathrm{U}-\mathrm{Pb}$ zircon ages of gabbros and syenite // The Neoproterozoic Timanide Orogen of Eastern Baltica. Eds. Gee D.G., Pease V.L. Geol. Soc. London Mem. 2004. V. 30. P. 69-74. DOI: 10.1144/GSL.MEM.2004.030.01.07

10. Steiger R. H., Jäger E. Subcomission of geochronology: convention of the use of decay constants in geo- and cosmochronology // Earth Planet. Sci. Lett. 1976. V. 36. No. 2. P. 359-362. DOI: $10.1016 / 0012-821 X(77) 90060-7$

11. Stacey J. S., Kramers I. D. Approximation of terrestrial lead isotope evolution by a two-stage model // Earth Planet. Sci. Lett. 1975. V. 26. No 2. P. 207-221. DOI: 10.1016/0012821X(75)90088-6

12. Ludwig K. SQUID 2: A User's Manual, rev. 12 Apr, 2009. Berkley Geochron. Ctr. Spec. Pub. 5. 2009. 110 p.

13. Jackson S. E., Norman J. P., William L. G., Belousova E. A. The application of laser ablation-inductively coupled plasmamass spectrometry to in situ U-Pb zircon geochronology // Chem. Geol. 2004. V. 211. P. 47-69. DOI: 10.1016/j.chemgeo.2004.06.017

14. Giovanardi T., Lugli F. The Hf-INATOR: a free data reduction spreadsheet for Lu/Hf isotope analysis // Earth Sci. Informat. 2017. V. 10. DOI: $10.1007 / \mathrm{s} 12145-017-0303-9$

15. Whitney D. L., Evans B. W. Abbreviations for names of rockforming minerals // Am. Mineral. 2010. V. 95. P. 185-187. DOI: 10.2138/am.2010.3371

16. Frost B. R., Barnes C. G., Collins W. J., Arculus R. J., Ellis D. J., Frost C. D. A geochemical classification for granitic rocks // Journal of Petrology. 2001. V. 42. P. 2033-2048. DOI: 10.1093/petrology/42.11.2033

17. Cox K. G., Bell J. D., Pankhurst R. J. The interpretation of igneous rocks. London, Chapman \& Hall, 1979. 450 p. DOI: 10.1007/978-94-017-3373-1

18. Middlemost E. A. K. Naming minerals in the magma/igneous rock system // Earth Science Review. 1994. V. 37. P. 215-224. DOI: 10.1016/0012-8252(94)90029-9

19. Boynton W. V. Cosmochemistry of the rare earth elements: meteorite studies // Rare earth element geochemistry. Ed. P. Henderson. Amsterdam, Elsevier, 1984. P. 63-114. DOI: 10.1016/B978-0-444-42148-7.50008-3

20. Sun S. S., McDonough W. F. Chemical and isotopic systematics of ocean basalts: Implication for mantle composition and processes // Magmatism in Ocean Basins. Eds.: Saunders, A.D., Norry, M.J. London, Geological Society, Special Publications. V. 42. P. 313-345. DOI: 10.1144/GSL.SP.1989.042.01.19

21. Goldstein S. J., Jacobsen S. B. Nd and Sr isotopic systematics of river water suspended material: implications for crustal evolution // Earth. Planet. Sci. Lett. 1988. V. 87. P. 249-265. DOI: 10.1016/0012-821X(88)90013-1

22. Liu X., Liu W., Si C. Petrogenesis and source rocks of the high-K calc-alkaline and shoshonitic I-type granitoids in the northwestern part of East Junggar, NWChina // Lithos. 2019. V. 326-327. P. 298-312. DOI: 10.1016/j.lithos.2018.12.033

23. Whalen J. B., Currie K. L., Chappell B. W. A-type granites: geochemical characteristics, discrimination and petrogenesis // Contrib. Mineral. Petrol. 1987. V. 95. P. 407-419. DOI: 10.1007/BF00402202

24. Defant M. J., Drummond M. S. Derivation of some modern arc magmas by melting of young subducted lithosphere // Nature. 1990. V. 347. No. 4. P. 662-665. DOI: 10.1038/347662a0

25. Martin H. Adakitic magmas: modern analogues of Archaean granitoids // Lithos. 1999. V. 46. P. 411-429. DOI: 10.1016/S0024-4937(98)00076-0

26. Watson E.B., Harrison T.M. Zircon saturation revisited: temperature and composition effects in a variety of crustal magma types // Earth. Planet. Sci. Lett. 1983. V. 64. P. 295-304. DOI: 10.1016/0012-821X(83)90211-X

27. Miller C. F., McDowell S. M., Mapes R. W. Hot and cold granites? Implications of zircon saturation temperatures and preservation of inheritance // Geological Society of America. 2003. V. 31. No. 6. P. 529-532. DOI: 10.1130/00917613(2003)031<0529:HACGIO>2.0.CO;2

28. Boehnke P., Watson E. B., Trail D., Harrison T. M., Schmitt A. K. Zircon saturation re-revisited // Chemical Geology. 2013. V. 351. P. 324-334. DOI: 10.1016/j.chemgeo.2013.05.028

29. Duan M., Niu Y., Sun P., Chen S., Kong J., Li J., Zhang Y., $\mathrm{Hu}$ Y., Shao F. A simple and robust method for calculating temperatures of granitoid magmas // Mineralogy and Petrology. 2021. V. 115, No. 6, in print. DOI: 10.1007/s00710-021-00769-5 30. Landenberger B., Collins W. J. Derivation of A-type granites from a dehydrated charnockitic lower crust: evidence from the Chaelundi Complex, Eastern Australia // Journal of Petrology. 1996. V. 37. P. 145-170. DOI: 10.1093/petrology/37.1.145 31. Savko K. A., Samsonov A. V., Larionov A. N., Chervyakovskaya M. V., Korish E. H., Larionova Yu. O., Bazikov N. S., Tsybulyaev S. V. A buried Paleoarchean core of the Eastern Sarmatia, Kursk block: U-Pb, Lu-Hf and Sm-Nd isotope mapping and paleotectonic application // Precambrian Research. 2021 V. 353. 106021. DOI: 10.1016/j.precamres.2020.106021

32. Цыбуляев С. В., Савко К. А., Червяковская М. В. Палеопротерозойские андезитовые порфириты Курского блока Восточной Сарматии: геохимия и источники расплавов Вестник Воронежского государственного университета. Серия: Геология. 2019. № 1. С. 26-38. DOI: $10.17308 / \mathrm{geol}-$ ogy.2019.1/1701

33. Terentiev R. A., Savko K. A., Santosh M. Paleoproterozoic evolution of the arc-back-arc system in the East Sarmatian Orogen (East European Craton): zircon SHRIMP geochronology and geochemistry of the Losevo volcanic suite // American Journal of Science. 2017. V. 317. P. 707-753. DOI: 10.2475/06.2017.03

34. Цыбуляев С. В., Савко К. А., Самсонов А. В., Кориш Е. $\mathrm{X}$. Палеопротерозойские рифтогенные вулканиты OIB- и MORB-типа Курского блока восточной Сарматии: петрология и геодинамика // Петрология. 2021. Т. 29. № 2. С. 136171. DOI: $10.31857 / \mathrm{S} 0869590321020060$ 


\title{
PETROLOGY, VOLCANOLOGY, GEOCHEMISTRY
}

UDC 552.11

DOI: https://doi.org/10.17308/geology.2021.3/3787

ISSN 1609-0691

Received: 30.11 .2021

Accepted: 01.12.2021

Published online: 17.12 .2021

\section{Palaeoproterozoic I-type granodiorites of the Lunevsky massif, Kursk Block, Sarmatia: U-Pb age, isotopic systematics and sources of melt}

\author{
(C) 2021 K. A. Savko ${ }^{1 凶}$, E. Kh. Korish ${ }^{1}$, N. S. Bazikov ${ }^{1}$, S. V. Tsybulyaev ${ }^{1}$, \\ V.S. Chervyakovskiy ${ }^{2}$, N. V. Kholina ${ }^{1}$, I. Hussain ${ }^{1}$ \\ ${ }^{I}$ Voronezh State University, 1 Universitetskaya pl., 394018, Voronezh. Russian Federation \\ ${ }^{2}$ Zavaritsky Institute of Geology and Geochemistry of the Ural Branch of the Russian Academy of \\ Sciences, 15 Akademika Vonsovskogo str., 620016, Ekaterinburg, Russian Federation
}

\begin{abstract}
Introduction: Recently age dating and isotope-geochemical data for the rocks of the Kursk Block allow for completely revision of the crustal growth history of Eastern Sarmatia in the Early Precambrian. However, there are very few data on the age, isotopic and elemental geochemistry of granodiorite-diorite massifs that are the most extensive manifestation of the Palaeoproterozoic magmatic event in the Kursk Block. This study contributes to the solution of this problem and is devoted to the Lunevsky massif of granodiorites. In the study, we focused on the Lunevsky granodiotite massif to contribute to the solution of the age crystallization and sources of melts on the basis of their geochemical study, U-Pb, Lu-Hf, and Sm-Nd isotope systematics.

Methodology: We carried out geochemical, U-Pb, Lu-Hf, and Sm-Nd studies of rocks from the Lunevksry massif to determine the age of formation and sources of melts of the granodiorites.

Results and discussion: In terms of mineral composition and geochemical characteristics, the granodiorites of the Lunevsky massif belong to I-type granitoids and have adakite signatures. The crystallization age of the massif is $2040 \mathrm{Ma}$. It has a post-tectonic position.

Conclusion: The Hf isotopic composition in zircon indicates the participation of several sources in the formation of granodiorite melt, including crustal Paleoarchean and juvenile mantle Paleoproterozoic protoliths.
\end{abstract}

Keywords: Kursk Block, Paleoproterozoic, granodiorites, U-Pb isotopic age, melt sources, isotope systematics

Funding: LA-ICP-MS study was supported by the state assignment of the «Geoanalitik» shared research facilities of IGG UB RAS (№ AAAA-A18-118053090045-8). The re-equipment and comprehensive development of the «Geoanalitik» shared research facilities of the IGG UB RAS is financially supported by the grant of the Ministry of Science and Higher Education of the Russian Federation (Agreement No. 07515-2021-680).

For citation: Savko K. A., Korish E. Kh., Bazikov N. S., Tsybulyaev S. V., Chervyakovskiy V. S., Kholina N. V., Hussain I. Palaeoproterozoic I-type granodiorites of the Lunevsky massif, Kursk Block, Sarmatia: $\mathrm{U}-\mathrm{Pb}$ age, isotopic systematics and sources of melt. Vestnik Voronezhskogo gosudarstvennogo universiteta. Seriya: Geologiya - Proceedings of Voronezh State University. Series: Geology, 2021, no. 4, pp. 4-23. DOI: https://doi.org/10.17308/geology.2021.4/3787

Conflict of interests: The authors declare the absence of obvious and potential conflicts of interest related to the publication of this article.

The content is available under Creative Commons Attribution 4.0 License.

\footnotetext{
$\bowtie$ Konstantin A. Savko, e-mail: ksavko@geol.vsu.ru 


\section{REFERENCES}

1. Savko K. A., Samsonov A. V., Bazikov N. S., Kozlova E. N. Paleoproterozoiskie granitoidy Tim-Yastrebovskoi struktury Voronezhskogo kristallicheskogo massiva: geokhimiya, geokhronologiya i istochniki rasplavov [Palaeoproterozic granitoids of the Tim-Yastrebovskaya structure, Voronezh Crystalline Massif: Geochemistry, geochronology, and melt sources]. Vestnik Voronezhskogo gosudarstvennogo universiteta. Seriya: Geologiya - Proceedings of Voronezh State University. Series: Geology, 2014, no. 2, pp. 56-78. (in Russ.).

2. Savko K. A., Samsonov A. V., Kholin V. M., Bazikov N. S. The Sarmatia megablock as a fragment of the Vaalbara supercontinent: Correlation of geological events at the Archaean-Paleoproterozoic transition. Stratigraphy and Geological Correlation, 2017, vol. 25, no. 2, pp. 123-145. DOI: $10.1134 / \mathrm{S} 0869593817020058$

3. Korish E. Kh., Savko K. A., Samsonov A. V., Chervyakovskaya M.V. Paleoproterozoic diorites of the Trosnyansky Massif within the Kursk Block of Sarmatia: U-Pb age, isotope systematics and sources of melts. Vestnik Voronezhskogo gosudarstvennogo universiteta. Seriya: Geologiya - Proceedings of Voronezh State University. Series: Geology, 2020, no. 1, pp. 87-99. DOI: 10.17308/geology.2020.1/2517 (in Russ.). 4. Tsybulyaev S. V., Savko K. A., Korish E. Kh., Chervyakovskaya M. V. Izotopno-geokhimicheskie osobennosti i geodinamicheskoe polozhenie porod shchebekinskogo kompleksa Kurskogo bloka vostochnoi Sarmatii [Isotopic-geochemical characteristics and geodynamical placement of the Schebekino complex rocks, Kursk Block, Eastern Sarmatia]. Petrologiya i geodinamika geologicheskikh protsessov [The petrology and geodynamics of the geological processes]. Irkutsk, September 6-13, 2021. V. 3. pp. 196-198. (in Russ.).

5. Al'bekov A. Yu., Ryborak M. V., Boiko P. S. Repernoe U-Pb izotopnoe datirovanie paleoproterozoiskikh gabbroidnykh formatsii Kurskogo bloka Sarmatii (Voronezhskii Kristallicheskii Massiv) [Benchmark isotopic dating of the palaeoproterozoic gabbroid formations of the Kursk Block, Sarmatia (Voronezh Crystalline Massif). Vestnik Voronezhskogo gosudarstvennogo universiteta. Seriya: Geologiya - Proceedings of Voronezh State University. Series: Geology, 2012, no. 2, pp. 84-94. (in Russ.).

6. Tsybulyaev S. V., Savko K. A. Geochemical typization of the paleoproterozoic volcanics bimodal series of the Kurbakinskoy suite, Kursk Block, Eastern Sarmatia. Vestnik Voronezhskogo gosudarstvennogo universiteta. Seriya: Geologiya - Proceedings of Voronezh State University. Series: Geology, 2017, no. 1, pp. 61-75. (in Russ.).

7. Tsybulyaev S. V., Savko K. A. U-Pb isotope age and tectonic position of the Paleoproterozoic andesite porphyrites, Kursk Block, Eastern Sarmatia. Vestnik Voronezhskogo gosudarstvennogo universiteta. Seriya: Geologiya - Proceedings of Voronezh State University. Series: Geology 2018, no. 3, pp. 29-35. DOI: 10.17308/geology.2018.3/1559 (in Russ.).

8. Bogdanova S., Gorbatschev R., Grad M., Guterch A., Janik T., Kozlovskaya E., Motuza G., Skridlaite G., Starostenko V., Taran L. EUROBRIDGE: new insight into the geodynamic evolution of the East European Craton. European Lithosphere Dynamics. Eds.: Gee, D.G., Stephenson, R.A. Geol. Soc. London Mem., 2006, vol. 32, pp. 599-628. DOI: 10.1144/GSL.MEM.2006.032.01.36

9. Larionov A. N., Andreichev V. A., Gee D. G. The Vendian alkaline igneous suite of northern Timan: ion microprobe $\mathrm{U}-\mathrm{Pb}$ zircon ages of gabbros and syenite. The Neoproterozoic Timanide Orogen of Eastern Baltica. Eds. Gee D.G., Pease V.L. Geol. Soc. London Mem., 2004. vol. 30, pp. 69-74. DOI: 10.1144/GSL.MEM.2004.030.01.07
10. Steiger R. H., Jäger E. Subcomission of geochronology: convention of the use of decay constants in geo- and cosmochronology. Earth Planet. Sci. Lett., 1976, vol. 36, no. 2, pp. 359-362. DOI: 10.1016/0012-821X(77)90060-7

11. Stacey J. S., Kramers I. D. Approximation of terrestrial lead isotope evolution by a two-stage model. Earth Planet. Sci. Lett., 1975 , vol. 26, no. 2, pp. 207-221. DOI: 10.1016/0012821X(75)90088-6

12. Ludwig K. SQUID 2: A User's Manual, rev. 12 Apr, 2009. Berkley Geochron. Ctr. Spec. Pub. 5. 2009. 110 p.

13. Jackson S. E., Norman J. P., William L. G., Belousova E. A. The application of laser ablation-inductively coupled plasmamass spectrometry to in situ $\mathrm{U}-\mathrm{Pb}$ zircon geochronology. Chem. Geol., 2004, vol. 211, pp. 47-69. DOI: 10.1016/j.chemgeo.2004.06.017

14. Giovanardi T., Lugli F. The Hf-INATOR: a free data reduction spreadsheet for Lu/Hf isotope analysis. Earth Sci. Informat., 2017, vol. 10. DOI: 10.1007/s12145-017-0303-9

15. Whitney D. L., Evans B. W. Abbreviations for names of rockforming minerals. Am. Mineral., 2010, vol. 95, pp. 185-187. DOI: 10.2138/am.2010.3371

16. Frost B. R., Barnes C. G., Collins W. J., Arculus R. J., Ellis D. J., Frost C. D. A geochemical classification for granitic rocks. Journal of Petrology, 2001, vol. 42, pp. 2033-2048. DOI: 10.1093/petrology/42.11.2033

17. Cox K. G., Bell J. D., Pankhurst R.J. The interpretation of igneous rocks. London, Chapman \& Hall, 1979. 450 p. DOI: 10.1007/978-94-017-3373-1

18. Middlemost E. A. K. Naming minerals in the magma/igneous rock system. Earth Science Review, 1994, vol. 37, pp. 215-224. DOI: 10.1016/0012-8252(94)90029-9

19. Boynton W. V. Cosmochemistry of the rare earth elements: meteorite studies. Rare earth element geochemistry. Ed. P. Henderson. Amsterdam, Elsevier, 1984. pp. 63-114. DOI: 10.1016/B978-0-444-42148-7.50008-3

20. Sun S. S., McDonough W. F. Chemical and isotopic systematics of ocean basalts: Implication for mantle composition and processes. Magmatism in Ocean Basins. Eds.: Saunders, A.D., Norry, M.J. London, Geological Society, Special Publications, vol. 42. pp. 313-345. DOI: 10.1144/GSL.SP.1989.042.01.19

21. Goldstein S. J., Jacobsen S. B. Nd and Sr isotopic systematics of river water suspended material: implications for crustal evolution. Earth. Planet. Sci. Lett., 1988, vol. 87, pp. 249-265. DOI: 10.1016/0012-821X(88)90013-1

22. Liu X., Liu W., Si C. Petrogenesis and source rocks of the high-K calc-alkaline and shoshonitic I-type granitoids in the northwestern part of East Junggar, NWChina. Lithos, 2019, vol. 326-327, pp. 298-312. DOI: 10.1016/j.lithos.2018.12.033

23. Whalen J. B., Currie K. L., Chappell B. W. A-type granites: geochemical characteristics, discrimination and petrogenesis. Contrib. Mineral. Petrol., 1987, vol. 95, pp. 407-419. DOI: 10.1007/BF00402202

24. Defant M. J., Drummond M. S. Derivation of some modern arc magmas by melting of young subducted lithosphere. Nature, 1990, vol. 347, no. 4, pp. 662-665. DOI: 10.1038/347662a0

25. Martin H. Adakitic magmas: modern analogues of Archaean granitoids. Lithos, 1999, vol. 46, pp. 411-429. DOI: 10.1016/S0024-4937(98)00076-0

26. Watson E. B., Harrison T. M. Zircon saturation revisited: temperature and composition effects in a variety of crustal magma types. Earth. Planet. Sci. Lett., 1983, vol. 64, pp. 295-304. DOI: 10.1016/0012-821X(83)90211-X

27. Miller C. F., McDowell S. M., Mapes R. W. Hot and cold granites? Implications of zircon saturation temperatures and preservation of inheritance. Geological Society of America, 2003, 
vol. 31, no. 6, pp. 529-532. DOI: 10.1130/00917613(2003)031<0529:HACGIO>2.0.CO;2

28. Boehnke P., Watson E. B., Trail D., Harrison T. M., Schmitt A. K. Zircon saturation re-revisited. Chemical Geology, 2013, vol. 351, pp. 324-334. DOI: 10.1016/j.chemgeo.2013.05.028

29. Duan M., Niu Y., Sun P., Chen S., Kong J., Li J., Zhang Y., $\mathrm{Hu}$ Y., Shao F. A simple and robust method for calculating temperatures of granitoid magmas. Mineralogy and Petrology, 2021, vol. 115, no. 6, in print. DOI: 10.1007/s00710-021-00769-5 30. Landenberger B., Collins W.J. Derivation of A-type granites from a dehydrated charnockitic lower crust: evidence from the Chaelundi Complex, Eastern Australia. Journal of Petrology, 1996, vol. 37, pp. 145-170. DOI: 10.1093/petrology/37.1.145 31. Savko K. A., Samsonov A. V., Larionov A. N., Chervyakovskaya M. V., Korish E. H., Larionova Yu. O., Bazikov N. S., Tsybulyaev S. V. A buried Paleoarchean core of the Eastern Sarmatia, Kursk block: U-Pb, Lu-Hf and Sm-Nd isotope mapping and paleotectonic application. Precambrian Research, 2021, vol. 353, 106021. DOI: 10.1016/j.precamres.2020.106021 32. Tsybulyaev S. V., Savko K. A., Chervyakovskaya M. V. Paleoproterozoic andesite porphyrites, Kursk Block, Eastern Sarmatia: geochemistry and sources of melts. Vestnik Voronezhskogo gosudarstvennogo universiteta. Seriya: Geologiya - Proceedings of Voronezh State University. Series: Geology, 2019, no. 1, pp. 26-38. DOI: 10.17308/geology.2019.1/1701 (in Russ.).

33. Terentiev R. A., Savko K. A., Santosh M. Paleoproterozoic evolution of the arc-back-arc system in the East Sarmatian Orogen (East European Craton): zircon SHRIMP geochronology and geochemistry of the Losevo volcanic suite. American Journal of Science, 2017, vol. 317, pp. 707-753. DOI: 10.2475/06.2017.03

34. Tsybulyaev S. V., Savko K. A., Samsonov A. V., Korish E. Kh. Paleoproterozoic OIB- and MORB-Type Rift Volcanics of the Kursk Block, Eastern Sarmatia: Petrology and Geodynamics. Petrology, 2021, vol. 29, no. 2, pp. 114-147. DOI: $10.1134 / \mathrm{S} 0869591121020065$
Савко Константин Аркадьевич - д.г.-м.н., профессор, заведующий кафедрой полезных ископаемых и недропользования, Воронежский государственный университет, Воронеж, Российская Федерация; e-mail: ksavko@geol.vsu.ru; ORCID https://orcid.org/0000-0002-7291-7024

Кориш Екатерина Хафисовна - ведущий инженер лаборатории комплексных исследований, Воронежский государственный университет, Воронеж, Российская Федерация; еmail: korish_k@rambler.ru; ORCID https://orcid.org/00000002-6573-1272

Базиков Николай Сергеевич - к.г.-м.н., доцент кафедры полезных ископаемых и недропользования, Воронежский государственный университет, Воронеж, Российская Федерация; e-mail: nickolasss@yandex.ru; ORCID https://orchid.org/0000-0002-0847-6498

Цыбуляев Сергей Владимирович - преподаватель кафедры полезных ископаемых и недропользования, Воронежский государственный университет, Воронеж, Российская Федерация, e-mail: stsybulyaev@bk.ru; ORCID https://orcid.org/0000-0002-0335-5187

Червяковский Василий Станиславович - заведующий группой пробоподготовки, Институт геологии и геохимии им. А. Н. Заварицкого, Екатеринбург, Российская Федерация, еmail: v.chervyakovskiy@mail.ru; ORCID https://orcid.org/0000-0002-0400-6819

Холина Наталья Викторовна - старший преподаватель кафедры полезных ископаемых и недропользования, Воронежский государственный университет, Воронеж, Российская Федерация; e-mail: holina_geol@mail.ru; ORCID https://orcid.org/0000-0002-7220-4358

Хуссейн Исрар - магистрант кафедры полезных ископаемых и недропользования, Воронежский государственный университет, Воронеж, Российская Федерация, e-mail: israrmazher@gmail.com;

Авторы прочитали и одобрили окончательный вариант рукописи.
Konstantin A. Savko - Dr. habil. in Geol.-Min., Professor, Head of the Department of Mineral Resources and Mineral Management Studies, Voronezh State University, Voronezh, Russian Federation; e-mail: ksavko@geol.vsu.ru; ORCID https://orcid.org/0000-0002-7291-7024

Ekaterina Kh. Korish - leading engineer, Integrated Research Laboratory, Voronezh State University, Voronezh, Russian Federation; e-mail: korish_k@ rambler.ru;

ORCID https://orcid.org/0000-0002-6573-1272

Nikolay S. Bazikov - PhD in Geology and Mineralogy, associate professor, Department of Mineral Resources and Mineral Management Studies, Voronezh State University, Voronezh, Russian Federation; e-mail: nickolasss@yandex.ru;

ORCID https://orchid.org/0000-0002-0847-6498

Sergey V. Tsybulyaev - lecturer, Department of Mineral Resources and Mineral Management Studies, Voronezh State University, Voronezh, Russian Federation; e-mail: stsybulyaev@bk.ru; ORCID https://orcid.org/0000-0002-0335-5187 Vasily S. Chervyakovskiy - head of the sample preparation group, Zavaritsky Institute of Geology and Geochemistry of the Ural Branch of the RAS, Ekaterinburg, Russian Federation, email: v.chervyakovskiy@ mail.ru;

ORCID https://orcid.org/0000-0002-0400-6819

Natalya $V$. Kholina - senior lecturer, Department of Mineral Resources and Mineral Management Studies, Voronezh State University, Voronezh, Russian Federation; e-mail: holina_geol@mail.ru; ORCID https://orcid.org/0000-0002-7220-4358

Israr Hussian - post graduate student, Department of Mineral Resources and Mineral Management Studies, Voronezh State University, Voronezh, Russian Federation; e-mail: israrmazher@gmail.com;

All authors have read and approved the final manuscript. 